6-3-2016

\title{
Imagined Identities: Defining the Racial Group in the Crime of Genocide
}

Carola Lingaas

University of Oslo

Follow this and additional works at: https://digitalcommons.usf.edu/gsp

\section{Recommended Citation}

Lingaas, Carola (2016) "Imagined Identities: Defining the Racial Group in the Crime of Genocide," Genocide Studies and Prevention: An International Journal: Vol. 10: Iss. 1: 79-106.

DOI:

http://dx.doi.org/10.5038/1911-9933.10.1.1377

Available at: https://digitalcommons.usf.edu/gsp/vol10/iss1/9

This Articles is brought to you for free and open access by the Open Access Journals at Digital Commons @ University of South Florida. It has been accepted for inclusion in Genocide Studies and Prevention: An International Journal by an authorized editor of Digital Commons @ University of South Florida. For more information, please contact digitalcommons@usf.edu. 


\begin{abstract}
The provisions on genocide protect four exclusive, amongst others the racial, groups. Yet, international criminal tribunals are manifestly uncomfortable with collective groupings and interpret 'race' rather inconsistently. Nevertheless, there is a tendency to a subjective approach based upon the perpetrator's perception of the targeted group. The victim's membership is accordingly not determined objectively, but by the perception of differentness. This article incorporates the theory of imagined identities into law, thereby providing tribunals with a tool to define 'race'. Its essence is that even if the group does not exist, it must be granted protection because of its perceived and thereby socially relevant differentness. This partially socio-anthropological approach will have to be brought into conformity with the principle of strict legality. It will be demonstrated that the theory of imagined identities has been applied in case law, thereby enhancing not only its theoretical, but also its practical relevance.
\end{abstract}

Keywords: imagined identity, genocide, racial group, subjective approach, Darfur Commission

"Everything you can imagine is real."

Pablo Picasso

\title{
Introduction
}

This quote by the famous painter Pablo Picasso summarizes the findings of this article: "Everything you can imagine is real" can be translated into international criminal law and the crime of genocide, in that even an imagined group membership can become real, despite originating in the imagination of the perpetrator. The social relevance of a group becomes legally relevant, if the group is treated as real and acquires an identity of its own. Identity is at the heart of every genocide and crucial to explain the crime. ${ }^{1}$ Individuals are targeted on the basis of their actual or perceived association to a group, even if the perpetrator's perception of the victim group is "wildly inaccurate". ${ }^{2}$

The Rome Statute of the International Criminal Court (ICC) defines the crime of genocide as follows: "'genocide' means any of the following acts committed with intent to destroy, in whole or in part, a national, ethnical, racial or religious group, as such...". ${ }^{3}$ This article will primarily focus on the racial group, yet in the context of the overall group membership of the victims of genocide. Where it appears appropriate and legally correct, the general analysis of the group membership will be applied to the racial group.

In the crime of genocide, the perpetrator selects and targets his victims because of their membership to a certain group. In order to convict a perpetrator for the crime of genocide, the courts have to prove that the victims belonged to one of the four protected groups. David Nersessian correctly recognizes that "[i]f an individual lacks membership in a protected group, genocide cannot occur with respect to that victim". ${ }^{4}$ The case studies of Cambodia and Rwanda will subsequently demonstrate the difficulties of determining the victims of genocide as members of a national, ethnical, racial or religious group. International criminal tribunals have largely tried to avoid defining group membership and in particular race. While sociology and anthropology, together with other disciplines, successfully adopted a contemporary approach to race as the perception of differentness, ${ }^{5}$ international criminal law is showing great discomfort with collective identities.

\footnotetext{
${ }^{1}$ David Moshman, "Us and Them: Identity and Genocide," Identity: An International Journal of Theory and Research 7, No. 2 (2007), 116.

${ }^{2}$ Moshman, "Us and Them", 116.

${ }^{3}$ Art. 6 of the Rome Statute of the ICC, UN Doc. A/CONF.183/9 of 17 July 1998.

${ }^{4}$ David Nersessian, Genocide and Political Groups (Oxford: Oxford University Press, 2010), 21.

${ }^{5}$ Lawrence Bobo, Foreword to Revisiting Race in a Genomic Age, by Barbara Koenig, Sandra Soo-Jin Lee and Sarah S. Richardson (New Brunswick: Rutgers University Press, 2008) , x. David Berreby, Us and Them: The Science of Identity (Chicago: The University of Chicago Press, 2008). Rogers Brubaker, "The Dolezal Affair: Race, Gender, and the Micropolitics of Identity," Ethnic and Racial Studies 39 (2016), 414-448. Rogers Brubaker, "Ethnicity, Race,
} 
The theory of imagined identities originates from Benedict Anderson's acclaimed book Imagined Communities ${ }^{6}$ and is an innovative method for determining the victim groups of genocide. The theory builds on a subjective approach based on the involved persons' perception, particularly the perpetrator's perception of the victim group. Such subjective approaches are commonplace in socio-anthropology for the definition of group membership in general and for the definition of a racial group in particular. ${ }^{7}$ The application of this approach by the international judiciary is, however, a recent development. One of its greatest benefits is the avoidance of objective parameters such as skin color, thus finally breaking with contentious means of objectively defining race. ${ }^{8}$ The assessment and clarification of the subjective approach, with help of the theory of imagined identity, is the objective of this paper. It will furthermore show how the theory of imagined identities applies to cases of genocide.

Nonetheless, a subjective approach to defining the racial victim group has to be brought into conformity with the principle of legality, particularly its elements of specificity and foreseeability, which will be examined in the next section. Following the review of the principle of legality, this article will look at how legal scholarship deals with race. Thereafter the theory of imagined identities is presented, as well as its application to genocidal cases. The jurisprudence by the ad hoc international criminal tribunals, namely the International Criminal Tribunal for the Former Yugoslavia (ICTY) ${ }^{9}$ and the International Criminal Tribunal for Rwanda (ICTR), ${ }^{10}$ on the victim groups of genocide is then analyzed. The definition of genocide by the Commission of Inquiry on Violations of International Humanitarian Law and Human Rights Law in Darfur (Darfur Commission) is also scrutinized. ${ }^{11}$ The Darfur Commission made a major contribution to defining the group membership in the crime of genocide by applying the theory of imagined identities. As such, it opened up for the application of this theory to future cases before the ICC, which still is in its infancy with regard to prosecutions of the crime of genocide. ${ }^{12}$

\section{The Implications of the Principle of Legality}

The principle of legality requires that an accused is not held guilty unless his act or omission constituted a crime under law at the time and location of its commission. ${ }^{13}$ The principle is construed to prevent the punishment for acts, which were reasonably believed not to be criminal when committed. ${ }^{14}$

Already in 1946, the Nuremberg Tribunal observed in its judgment against the major war criminals that a fundamental principle of all law, international as well as domestic, was that there

and Nationalism," Annual Review of Sociology 35 (2009), 21-42. Kurt Glaser and Stefan Possony, Victims of Politics: The State of Human Rights (New York, Columbia University Press, 1979), 67. In 2000, the US census introduced selfidentification, thus perception, regarding racial categorization in asking "What is this person's race? Mark one or more races to indicate what this person considers himself/herself to be". Cited in Michael Banton, What We Know about Race and Ethnicity (New York: Berghahn Books, 2015), 2.

${ }^{6}$ Benedict Anderson, Imagined Communities: Reflections on the Origin and Spread of Nationalism (London: Verso, 2006).

${ }^{7}$ For example race scholar Paul Gilroy talks about "the imagined community of a racialized group", Paul Gilroy, Against Race: Imagining Political Culture Beyond the Color Line (Cambridge: Harvard University Press, 2000), 38.

${ }^{8}$ Caroline Fournet, The Crime of Destruction and the Law of Genocide: Their Impact on Collective Memory (Aldershot: Ashgate, 2007), 59. Gilroy, Against Race, 37 asks "if 'race' is a useful way of classifying people, then how many 'races' are there?".

${ }^{9}$ Established by Security Council Resolution S/RES/827 (25 May 1993). Official title: International Tribunal for the Prosecution of Persons Responsible for Serious Violations of International Humanitarian Law Committed in the Territory of the Former Yugoslavia since 1991.

${ }^{10}$ Established by Security Council Resolution S/RES/955 (8 November 1994). Official title: International Criminal Tribunal for the Prosecution of Persons Responsible for Genocide and Other Serious Violations of International Humanitarian Law Committed in the Territory of Rwanda and Rwandan Citizens Responsible for Genocide and Other Such Violations Committed in the Territory of Neighboring States between 1 January and 31 December 1994.

${ }^{11}$ UN Security Council Resolution, UN Doc. S/RES/1564 (2004) of 18 September 2004.

12 The ICC has to date not dealt with the protected groups of genocide.

${ }^{13}$ Theodor Meron, War Crimes Law Comes of Age: Essays (Oxford: Clarendon Press, 1998), 244-245.

${ }^{14}$ Meron, War Crimes Law, 245; The Prosecutor v. Stanislav Galić, Trial Chamber Judgment, December 5, 2003, IT-98-29-T, para. 93. 
could be no punishment for a crime without a pre-existing law, and furthermore that "the maxim nullum crimen sine lege is not a limitation of sovereignty, but is in general a principle of justice". ${ }^{15}$ Nowadays the maxim is more than just a principle of justice; it is an internationally recognized human right, embedded in the right to a fair trial. ${ }^{16}$ The principle of legality, whereby individuals may not be punished if their conduct had not been previously criminalized by law,

has been so extensively proclaimed in international human rights treaties with regard to domestic legal systems and so frequently upheld by international criminal courts with regard to international prosecution of crimes, that it is warranted to hold that by now it has the status of a peremptory norm (jus cogens). ${ }^{17}$

Nullum crimen sine lege has transformed into a rule of law that fundamentally influenced international criminal law. ${ }^{18}$ While the principle is not explicitly enshrined in the Statutes of the ad hoc international criminal tribunals, it is contained in Arts. 22-24 of the Rome Statute of the ICC. Under the heading "General Principles of Criminal Law", the Statute specifically lists nullum crimen sine lege (Art. 22), nulla poena sine lege (Art. 23), according to which no punishment may be imposed except as provided by law and, lastly, nulla poena sine praevia lege (Art. 24) or, no penalty without previous law. ${ }^{19}$ The Rome Statute makes clear that the principle of legality consists of several elements, namely the strict construction of the definition of a crime, the prohibition of extension by analogy and in dubio pro reo, whereby in case of ambiguity the definition shall be interpreted in favor of the person under investigation or prosecution (Art. 22 (2)).

The principle of legality restricts any excessive interpretative activity in that the judges must respect its most important corollaries: the principle of strict construction and in dubio pro reo (when in doubt, for the accused). ${ }^{20}$ Due to the principle of strict construction, the judges may not adopt a method of interpretation that unduly broadens the definition of the crimes. In other words: the respective provision may only be applied to conduct that the drafters expressly intended to criminalize. ${ }^{21}$

The principle of legality is twofold: first, a criminal law provision needs to be sufficiently clear and specific for the perpetrator to foresee that he could become criminally liable, thereby giving him the opportunity to adjust his behavior in order to avoid sanctions. ${ }^{22}$ Secondly, the law has to be unambiguous and accessible for judges to render uniform and coherent judgments, without expansively interpreting the respective provisions. The latter also serves the purpose of protecting citizens from arbitrary judicial actions. ${ }^{23}$ There remain therefore two opposites: on the one hand, the principle of legality imposes interpretative boundaries. On the other hand, a broad interpretation may protect more victims. Thus, while the judges may interpret and apply the law on the crime of genocide, they are not permitted to create new law by means of expansive judicial interpretation. The interpretation of race is therefore limited to what the drafters intended to criminalize and cannot go beyond what is understood to be a racial group.

The theory of imagined identities challenges the principle of legality in several ways. The narrow definition of the crime of genocide will inevitably be broadened if the group membership is

\footnotetext{
${ }^{15}$ Nuremberg International Military Tribunal (IMT), Trial of the Major War Criminals Before the IMT, Judgment (November 14, 1945 - October 1, 1946), Official Text in the English Language (1947), 219.

${ }^{16}$ Kenneth Gallant, The Principle of Legality in International and Comparative Criminal Law (Cambridge: Cambridge University Press, 2009), 3. Beth Van Schaack, "Crimen Sine Lege: Judicial Lawmaking at the Intersection of Law and Morals", Georgetown Law Journal 97 (2008), 124.

${ }^{17}$ The Prosecutor v. Ayyash et al., Interlocutory Decision on the Applicable Law: Terrorism, Conspiracy, Homicide, Perpetration, Cumulative Charging, February 16, 2011, STL-11-01/I/AC/R176bis, para. 76.

${ }^{18}$ Gallant, Principle of Legality, 3.

${ }^{19}$ Ibid., 12.

${ }^{20}$ The Prosecutor v. Katanga, Judgment pursuant to Article 74 of the Statute, March 7, 2014, ICC-01/04-01/07, para. 51.

${ }^{21}$ Ibid.

${ }^{22}$ Van Schaack, 'Crimen Sine Lege', 121.

${ }^{23}$ Ibid.,
} 
defined by the perpetrator's perception. From initially protecting four exclusive groups, the ambit of the provision would be expanded to cover any victim perceived as belonging to one of the four groups. Richard Ashby Wilson points to the challenges that a perception-based approach might entail: "If a group's existence is not a fact but a changeable chimera dependent on a subjective state of mind, then the whole edifice of the [ICTR]'s mandate to prosecute the crime of genocide is potentially undermined" ${ }^{24}$ By basing a legal definition on the perpetrator's perception, the principle of strict construction and the related element of specificity are challenged. The principle of foreseeability is also affected, since the application of the criminal provision cannot possibly be foreseen if its content is fully dependent on a person's perception or imagination. This article will demonstrate that the theory of imagined identities nevertheless is compatible with the principle of legality, despite pushing its boundaries. It is an innovative, yet legitimate legal tool for the identification of the victim groups in the crime of genocide. The next section will give an insight into the historical development of race and its protection by the Convention on the Prevention and Punishment of Genocide (Genocide Convention), ${ }^{25}$ before further discussing the theory of imagined identities.

\section{The Authoritative Source: The Genocide Convention}

The proponents of different social studies often employ the term genocide more broadly as the intended mass killing of a group of people. ${ }^{26}$ International criminal law - bound by the principle of strict legality - limits its protection against genocide to the racial, ethnical, religious and national groups. In order to convict a perpetrator of the crime of genocide, all the legal elements of the crime have to be fulfilled, including the protected victim group. ${ }^{27}$ The narrow definition of genocide and the four protected groups is definitive for legal purposes, although it is seen as seriously flawed by non-legal genocide scholars. ${ }^{28}$

During the drafting of the Rome Statute of the ICC, the state delegates made clear that the 1948 Genocide Convention contained a generally acceptable definition of the crime of genocide that could and should be used in the Statute. ${ }^{29}$ Indeed, genocide was the only crime that received a quick and unanimous consensus without any further discussion on what defines a racial group. ${ }^{30}$ Not only Art. 6 Rome Statute, but also the respective provisions in the ICTY and ICTR Statute are verbatim to Art. II Genocide Convention. The International Court of Justice (ICJ) has furthermore declared that Art. II Genocide Convention is customary international law and jus cogens, ${ }^{31}$ making

${ }^{24}$ Richard Ashby Wilson, "Crimes against Humanity and the Conundrum of Race and Ethnicity at the International Criminal Tribunal for Rwanda," in In the Name of Humanity: The Government of Threat and Care, ed. Ilana Feldman and Miriam Ticktin (Durham: Duke University Press, 2010), 52.

${ }^{25}$ Adopted by Resolution 260 (III)A of the UN General Assembly on December 9, 1948.

${ }^{26}$ Examples include: Frank Chalk and Kurt Jonassohn, The History and Sociology of Genocide: Analyses and Case Studies (New Haven: Yale University Press, 1990), 23. Alexander Laban Hinton, "The Dark Side of Modernity," in Annihilating Difference: the Anthropology of Genocide, ed. Alexander Laban Hinton (Berkeley: University of California Press, 2002), 4. See also David Lisson, "Defining 'National Group' in the Genocide Convention: a Case Study of Timor-Leste," Stanford Law Review (2008), 1463, providing a brief summary of different approaches to the definition of genocide that have no legal force.

${ }^{27}$ There are diverging views as to whether the victim group is an objective or subjective element. Some include the victim groups into the mens rea, while others see the victim group as an element of the actus reus. The wording of Art. II Genocide Convention suggests the latter, since the element of a 'group' is part of each genocidal act. For example, Art. II(a) reads: "Killing members of the group". The group is therefore part of the objective elements of the crime. See for further discussion: Antonio Cassese, International Criminal Law (Oxford: Oxford University Press, 2008), 138.

${ }^{28}$ Moshman, "Us and Them", 116.

${ }^{29}$ M. Cherif Bassiouni, The Legislative History of the International Criminal Court, Summary Records of the 1998 Diplomatic Conference (New York: Transnational Publishers, 2005), 92, note 20.

${ }^{30}$ Hermann Von Hebel and Darryl Robinson, "Crimes Within the Jurisdiction of the Court," in The International Criminal Court: The Making of the Rome Statute - Issues, Negotiations, Results, ed. Roy Lee (The Hague: Kluwer Law International, 1999), 89 .

${ }^{31}$ Reservations to the Convention on the Prevention and Punishment of the Crime of Genocide, ICJ Advisory Opinion (1951) 23. Case Concerning Armed Activities on the Territory of the Congo (Democratic Republic of the Congo v. Rwanda), New Application: 2002, ICJ Judgment (February 3, 2006), para. 64 with reference to Application of the Convention on the Prevention and Punishment of the Crime of Genocide (Bosnia and Herzegovina v. Yugoslavia). ICJ Judgment on Preliminary 
its content definitive for any legal analysis of the crime. The following discussion of the crime of genocide and the protected victim groups is therefore based on Art. II Genocide Convention as the authoritative definition.

The travaux préparatoires to the Genocide Convention reveal that the four protected groups - the national, ethnical, racial and religious group - were intended to be an exhaustive list. The drafters considered them to be cohesive, stable and permanent. ${ }^{32}$ Therefore these groups merited more protection than loose groups to which membership could be easily gained or renounced, such as political groups. ${ }^{33}$ While there undoubtedly were political reasons to exclude political groups from the protection of the Genocide Convention, the International Law Commission in 1996 restated that the exclusion occurred because "this type of group was not considered to be sufficiently stable". ${ }^{34}$

Historical research shows that the idea of race always carried more meanings than mere physical differences. In fact, physical variations in the human species have no meaning except the social values that humans apply to them. ${ }^{35}$ David Davis concludes that "[1]ike serfdom, social castes, and royal or noble 'blood', concepts of race influence perception, including self-perception, and can above all represent a shared historical experience, such as the African Americans in the United States". ${ }^{36}$ Perception is of paramount importance for the legal definition of a racial group in the crime of genocide, as this article will demonstrate.

The so-called races of humankind are recognized to be incidental and arbitrary social mechanisms invented during the eighteenth century; they helped organize the populations encountered and conquered during European colonialism. ${ }^{37}$ Thus, race became a by-product of Europe's religious, economic and imperial expansion during colonialism. ${ }^{38}$ However, Benedict Anderson, the author of Imagined Communities, disagrees that race originates in colonialism; and instead finds its origin in ideologies of class, for example, the claim of contamination of "white" or "blue" (aristocratic) blood by inferior (racial) classes. ${ }^{39}$ The idea of blood purity has transgressed many societies, for instance, during the Jim Crow legislation in the United States, when most Southern states adopted the "one-drop rule", according to which an individual with any black ancestry was deemed black. ${ }^{40}$

When the Genocide Convention was drafted, the contemporary understanding of race heavily influenced its legal correlative. The reference to races was not uncommon at the time. Indeed, race was perceived as a combination of two concepts. The first concept embraces the notion of nation states as well as sub-groups of people. ${ }^{41}$ The second concept contains the idea of biologically distinct races, determined by their bloodline. ${ }^{42}$ The Polish-Jewish lawyer, Raphael Lemkin, created the term

Objections (1996), para. 31.

${ }^{32}$ UN Doc. A/C.6./SR.74 (October 15, 1948).

${ }^{33}$ Ibid. William Schabas, Genocide in International Law, $2^{\text {nd }}$ ed. (Cambridge: Cambridge University Press, 2009), 117, 151, 153-160.

${ }^{34}$ International Law Commission (ILC), Report of the ILC on the work of its forty-eighth session, UN Doc. A/51/10, 45 (1996).

${ }^{35}$ American Anthropological Association (AAA). Statement on 'Race' (1998), accessed April 7, 2016, http://www.aaanet.org/ stmts/racepp.htm.

${ }^{36}$ David Davis, “Constructing Race: A Reflection", The William and Mary Quarterly (1997), 7.

${ }^{37}$ Richard Cooper, Jay Kaufman and Ryk Ward, “Race and Genomics,” New England Journal of Medicine (2003), 1166; AAA, Statement on 'Race'.

${ }^{38}$ Davis, "Constructing Race", 7.

${ }^{39}$ Anderson, Imagined Communities, 149.

${ }^{40}$ Ian Haney López, White by Law: The Legal Construction of Race (New York: New York University Press, 2006), 83. Banton, Race and Ethnicity, 2. Sharona Hoffman, "Is There a Place for "Race" as a Legal Concept?," Arizona State Law Journal (2004), 1129-1130.

${ }^{41}$ Diane Amann confirms that race was used in the then-current fashion to describe European subgroups, like the Germans, Poles and the Jews (Diane Amann, "Group Mentality, Expressivism, and Genocide," International Criminal Law Review (2002), 98). William Schabas, "Groups Protected by the Genocide Convention," ILSA Journal for International and Comparative Law (2000), 381.

42 This can be inferred from the fact that the Genocide Convention was drafted in reaction to the Holocaust, and as such was influenced by historical facts (Machteld Boot, Genocide, Crimes Against Humanity, War Crimes: Nullum Crimen Sine Lege and the Subject Matter Jurisdiction of the International Criminal Court (Antwerpen, Intersentia (2002)), 417). 
Lingaas

genocide by combining two words genos (ancient Greek for race or tribe) and cide (from the Latin word caedere for to kill). ${ }^{43}$ Lemkin's study Axis Rule in Occupied Europe, which first formulated the proposed crime of genocide, illustrates that the different European nations or subgroups like the Germans, Poles and Jews were seen as different races. ${ }^{44}$

Yet the concept of race was also shaped by the Nazi racial ideology. The Holocaust was still ongoing when Lemkin published his book, and undoubtedly the Nazi propaganda terminology influenced his use of the term race. The Nazi racial ideology demanded the purity of the Aryan blood. Adolf Hitler created the concept a homogenous German people as the Aryan master race (the so-called Herrenrasse) in an attempt to justify genocide as a sacred purpose of the biologically superior German people. ${ }^{45}$ Differences between the Aryan and Jewish race were "biologized into an immutable physiological essence that could not be changed". ${ }^{46}$ As such, the Jewish race was portrayed as unhuman, a threat to the Aryan race and had therefore to be completely destroyed. ${ }^{47}$ The Nazi racial legislation in the Nuremberg laws ${ }^{48}$ determined Jewry according to blood relationship and in particular as far back as grandparental inheritance. ${ }^{49}$ Races were accordingly defined by biology and heredity.

In the past fifty years, the concept of race has changed considerably. In particular, the conflation of race with nationality has ceased. Nowadays it would be rather surprising if anyone referred to the Poles, Dutch or Jews as a separate race. The scientific progress in genetics and biology of the past decades determined that there is no gene for race and that it is scientifically incorrect to speak of different human races. ${ }^{50}$ In its final report, the Commission of Experts on Rwanda emphasized that "to recognize that there exists discrimination on racial or ethnic grounds, it is not necessary to presume or posit the existence of race or ethnicity itself as a scientifically objective fact". ${ }^{51}$ Colloquially, however, the meaning of race is still very much linked to the outer appearance of people, particularly skin color. In conclusion it can be noted that there are no biologically different human races. ${ }^{52}$ Yet people's features are still commonly used to determine their race. The next section reveals the limitations of the Genocide Convention, especially when the victim group is not easily defined as a national, racial, ethnical or religious group.

\section{Practical Significance: Rwanda and Cambodia}

The designation of a genocidal victim to one of the four protected groups is not only of theoretical importance; the group membership of the victim is an element of the crime of genocide. ${ }^{53}$ If the victim cannot be classified as a member of a racial, ethnical, national or religious group, the crime

\footnotetext{
${ }^{43}$ Raphael Lemkin, Axis Rule in Occupied Europe: Laws of Occupation, Analysis of Government, Proposals for Redress (Washington: Carnegie Endowment for International Peace, Division of International Law, 1944), 79.

${ }^{44}$ Lemkin, Axis Rule in Europe, 87-88.

${ }^{45}$ Henry Jr. King, "Genocide and Nuremberg," in The Criminal Law of Genocide, ed. Ralph Henham and Paul Behrens (Aldershot: Ashgate, 2007), 30.

${ }^{46}$ Hinton, “Dark Side of Modernity", 14.

${ }^{47}$ Lemkin, Axis Rule in Europe, 81, 86-87. Scott Straus affirms that Lemkin grounded his work in the Nazis' commission of genocide based on their preoccupation with biology (Scott Straus, "Contested Meanings and Conflicting Imperatives: a Conceptual Analysis of Genocide," Journal of Genocide Research (2001), 365.

${ }^{48}$ The Nuremberg laws consisted of two distinct laws, resulting in a direct order from Hitler: the Reich citizenship law (Reichsbürgergesetz) and The Law for the Protection of German Blood and German Honor (Gesetz zum Schutz des deutschen Blutes und der deutschen Ehre).

${ }^{49}$ The definition of a German Reich citizen is contained in Art. 2(1) of the Reichsbürgergesetz Reichsgesetzblatt (September 16, 1935), 1146, accessed April 1, 2016, published by the Austrian National Library: http://alex.onb.ac.at/cgi-content/ale $\underline{x}$ ?apm=0\&aid=dra\&datum $=19350004 \&$ seite $=00001146 \&$ zoom $=2$.

${ }^{50}$ No genes have been identified that are shared by all members of one "race" (and hence could explain a common racial appearance) that are not also present at substantial levels in other races (thereby failing to sort individuals into races), see: Leda Cosmides, John Tooby and Robert Kurzban, "Perceptions of Race," Trends in Cognitive Sciences (2003), 173. For more insight into the discussion: Hoffman, “'Race' as a Legal Concept?", 1093-1159.

${ }^{51}$ United Nations, Final Report of the Commission of Experts Established Pursuant to Security Council Resolution 935 (1994), December 9, 1994 (UN Doc. S/1995/1405, Annex, para. 159).

${ }^{52}$ Michael Banton, Racial Theories (Cambridge: Cambridge University Press, 1998), 196, 212.

${ }^{53}$ See footnote 27.
} 
is legally not genocide. Two examples illustrate the practical significance of the narrow protection awarded by the Genocide Convention: Cambodia under the Khmer Rouge from 1975-1979 and Rwanda during the 1994 genocide. These examples will not specifically deal with the racial group. Instead, they intend to show the difficulties to determine the groups protected by the Genocide Convention.

The atrocities committed in Cambodia by the Khmer Rouge regime have occasionally been labelled auto-genocide since the Khmer Rouge regime targeted parts of its own citizens. ${ }^{54}$ Most victims were intellectuals, bourgeoisie, other political or social class enemies, as well as urban residents, and belonged to the Khmer majority group. ${ }^{55}$ A 1985 UN report concluded that the definition of genocide did not exclude cases, in which the victims were part of the violator's own group. ${ }^{56}$ Indeed, the perpetrators and the majority of the victims were members of the same nationality, religion, ethnicity and race: they were all Khmer. The crimes committed were possibly not genocidal acts, because they targeted primarily political, economic or social groups ${ }^{57}$ But the Khmer Rouge regime also targeted ethnic Vietnamese and the Cham Muslim minority group. ${ }^{58}$ The charges in the trial at the UN-backed Extraordinary Chambers in the Courts of Cambodia (ECCC) against Nuon Chea and Khieu Samphan (Case 002/02) include genocide against these two minority groups only, precisely because of the limitations of the Genocide Convention to protect four exhaustive categories of groups ${ }^{59}$ In 1999, a UN report by a Group of Experts classified "the Muslim Cham as an ethnic and religious group; the Vietnamese communities as an ethnic and, perhaps, a racial group; and the Buddhist monkhood as a religious group" ${ }^{60}$ The report reads furthermore: "whether the Khmer Rouge committed genocide with respect to part of the Khmer national group turns on complex interpretative issues, especially concerning the Khmer Rouge's intent with respect to its non-minority-group victims". ${ }^{61}$ The Group of Experts did not further qualify the crimes committed. The trial in the case 002/02 before the ECCC will have to reach a verdict whether the Khmer Rouge committed genocide and whether the victims fall under one of the four protected groups. The indictment did not include genocide against the Khmer national group. Thus, the likely outcome is a conviction of the accused for genocide against the Muslim Cham and the Vietnamese minority groups.

The other example that shows the narrow protection of the Genocide Convention is Rwanda. There was a risk that the perpetrators of the Rwandan genocide would be acquitted because their victims could not be qualified as members of an ethnical, racial, national or religious group. Indeed, one of the main challenges for the ICTR was the classification of the Hutu and Tutsi as two distinct groups, as subsequent sections of this paper will discuss. Technically speaking, the Tutsi and Hutu did not belong to different ethnicities. ${ }^{62}$ According to Katy Grady "it is virtually impossible, on an objective, factual level, to distinguish between Tutsi and Hutu". ${ }^{33}$ Other scholars suggest that the

\footnotetext{
${ }^{54}$ Fournet, Crime of Destruction, 48. Payam Akhavan, Reducing Genocide to Law: Definition, Meaning, and the Ultimate Crime (Cambridge: Cambridge University Press, 2012), 133.

${ }^{55}$ Ben Kiernan, Blood and Soil: A World History of Genocide and Extermination from Sparta to Darfur (New Haven: Yale University Press, 2007), 546-547.

${ }^{56}$ Benjamin Whitaker, Revised and Updated Report on the Question of the Prevention and Punishment of the Crime of Genocide, July 2, 1985 (UN Doc. E/CN.4/Sub.2/1985/6, para. 31).

${ }^{57}$ Steven Ratner and Jason Abrams, Accountability for Human Rights Atrocities in International Law: Beyond the Nuremberg Legacy (New York: Oxford University Press, 1997), 306-312; Akhavan, Reducing Genocide to Law, 134.

${ }^{58}$ Schabas, Genocide in International Law, 149-150. Nersessian, Genocide and Political Groups, 90.

59 “Case 002/02," Extraordinary Chambers in the Courts of Cambodia, accessed May 18, 2016, http://www.eccc.gov.kh/en/ case/topic/1299.

${ }^{60}$ United Nations, Report of the Group of Experts for Cambodia Established Pursuant to General Assembly Resolution 52/135, March 15, 1999 (UN Doc. A/53/850 and S/1999/231, Annex, para. 63).

${ }^{61}$ Ibid., para. 65.

${ }^{62}$ The Prosecutor v. Akayesu, Trial Chamber Judgment, September 2, 1998, ICTR-96-4-T, para. 516. William Schabas, “The Crime of Genocide in the Jurisprudence of the International Criminal Tribunals for the Former Yugoslavia and Rwanda," in International and National Prosecution of Crimes Under International Law, ed. Horst Fischer, Claus Kress and Sascha Rolf Lüder (Berlin: Berlin Verlag, 2001, 450). Amann, "Group Mentality", 94.

${ }^{63}$ Katy Grady, “The Genocide Convention's Protected Groups: A Place for Gender?” in Protecting Humanity: Essays in
} 
Hutu and Tutsi might be two distinct races: William Schabas notes that the category of racial group "might have seemed the best choice, but some of the judges were probably uncomfortable with the notion itself and its whiff of racism" ${ }^{64}$ or, in other words, "general discomfort with the term 'racial group' may explain why the ICTR was reluctant to classify the Tutsi as a racial group". 65 Van den Herik agrees that "[the Tutsi] would probably have fitted the description of a racial group better", ${ }^{66}$ as do Nagan and Rodin who assert that "perhaps race was a defining element in the tardy commitment to the Rwandan tribunal". ${ }^{67}$ Subsequent sections will discuss how the ICTR categorized the Tutsi victims of the Rwandan genocide. But not only Tutsi became victims of the atrocities. Hutu moderates, who sympathized with the Tutsi, were also targeted. Since the Hutu were not targeted for reasons of group membership, but rather for taking a political stance, these crimes could not be legally qualified as genocide. ${ }^{68}$

Four Corner Posts

There is an ongoing scholarly debate as to the usefulness of distinguishing the four protected groups. ${ }^{69}$ William Schabas suggests using the four terms - national, ethnical, racial and religious - as "four corner posts that delimit an area within which a [sic] myriad of groups covered by the Convention find protection", ${ }^{70}$ whereby the groups are in a dynamic and synergistic relationship, each contributing to the construction of the other. ${ }^{71}$ This approach, which sees no need to definitively assign the victim to one particular group, because of multiple group characteristics, has also been called ensemble or holistic approach. ${ }^{72}$ There is undoubtedly a risk of an overlap between the four categories. However, the creation of a generic, undefined group contradicts the internationally recognized maxim ut res magis valeat quam pereat, where each word in a legal text carries its distinct meaning. ${ }^{73}$ Difficulties in defining the protected groups should not lead to creating an undefined area, in which myriad of groups are contained within the four corner posts of nationality, ethnicity, race and religion. The intention of the Genocide Convention's drafters was to limit the protection to racial, ethnical, national and religious groups. The expansion of the Convention to an undefined number of groups would contradict its objective of a restrictive application. ${ }^{74}$ Lars Berster considers such a de facto dissolution of a key element of the crime not to be reconcilable with the principle of legality. ${ }^{75}$

International Law and Policy in Honour of Navanethem Pillay, ed. Chile Eboe-Osuji (Leiden: Martinus Nijhoff Publishers, 2010), 177.

${ }^{64}$ William Schabas, "Judicial Activism and the Crime of Genocide," in Judicial Creativity at the International Criminal Tribunals, ed. Shane Darcy and Joseph Powderly (Oxford: Oxford University Press, 2010), 71.

${ }^{65}$ Schabas, "Groups Protected", 380.

${ }^{66}$ Larissa Van den Herik, The Contribution of the Rwanda Tribunal to the Development of International Law (Leiden: Martinus Nijhoff, 2005), 129.

${ }^{67}$ Winston Nagan and Vivile Rodin, "Racism, Genocide, and Mass Murder: Towards a Legal Theory about Group Deprivations," National Black Law Journal (2002-2004), 216.

${ }^{68}$ The Prosecutor v. Akayesu, Trial Chamber Judgment, September 2, 1998, ICTR-96-4-T, para. 721. Nersessian, Genocide and Political Groups, 21.

${ }^{69}$ Schabas, Genocide in International Law, 129. Amann, “Group Mentality", 109-113. Peter Quayle, “Unimaginable Evil: The Legislative Limitations of the Genocide Convention," International Criminal Law Review (2005), 370. Gerhard Werle, Principles of International Criminal Law (The Hague: T.M.C. Asser Press, 2005), 194. Allard K. Lowenstein International Human Rights Clinic, Yale Law School, Persecution of the Rohingya Muslims: Is Genocide Occurring in Myanmar's Rakhine State? A Legal Analysis (2015), 41. Claus, Kress, “The Crime of Genocide Under International Law," International Criminal Law Review (2006), 475.

${ }^{70}$ Schabas, Genocide in International Law, 129.

${ }^{71}$ Ibid.

${ }^{72}$ Amann, "Group Mentality", 109-113. Lars Berster, "Article II," in Convention on the Prevention and Punishment of the Crime of Genocide: A Commentary, ed. Christian Tams, Lars Berster and Björn Schiffbauer (Munich: C.H. Beck, 2014), 102. Werle, Principles of International Criminal Law, 194.

${ }^{73}$ Kress, “The Crime of Genocide", 475. Berster, "Article II", 102. John Quigley, The Genocide Convention: An International Law Analysis (Aldershot: Ashgate, 2006), 149.

${ }^{74}$ Matthew Lippman, "Genocide: The Crime of the Century," Houston Journal of International Law 23 (2000), 476.

${ }^{75}$ Berster, "Article II", 102. 
Another argument against an ensemble approach is the fact that the genocidal perpetrator defines his victims by reducing their identity to what he perceives to be specific group identity markers. The victims are reduced to one aspect of their identity and stigmatized because of that particular dimension, thereby rendering other dimensions of their identity marginal. ${ }^{76}$ Such process occurred, for example, in Germany prior to the Holocaust. The Nazi ideology determined that the Jews were a distinct group and could no longer be part of the racially defined German nation. Their Jewishness became the defining identity marker. ${ }^{77}$ It is, in other words, the perpetrator's perception of the victims that determines whether or not they are covered by the protection of Art. II Genocide Convention. Helen Klann and Phillipa KcKenzie note that "in cases where it is unclear whether a victim belonged to a protected group, the perception of the perpetrator is most relevant. Where the perpetrator perceived the victim as belonging to a group, the victim should be considered to belong to that group". ${ }^{78}$ Caroline Fournet emphasizes that the Genocide Convention "wrongly affords protection to 'racial' groups, in spite of the fact that there are no such groups except in the minds of the perpetrators". ${ }^{79}$ The perpetrator identifies his victims by what he perceives to be their decisive characteristic.

According to the Darfur Commission, the principle of effectiveness dictated that international rules were to be given maximum effect - or in its Latin terms ut res magis valeat quam pereat, thereby suggesting that Art. II Genocide Convention should be construed as effectively as possible, in light of its object and purpose ${ }^{80}$ The ICJ recognized the principle of effectiveness as "one of the fundamental principles of interpretation of treaties, consistently upheld by international jurisprudence" ${ }^{81}$ According to this principle, the terms of a treaty are ensured effectiveness in consideration of its object and purpose together with good faith, the so-called effet utile. ${ }^{82}$ Hence, Art. II Genocide Convention has to be interpreted effectively, giving maximum effect to all the protected groups, including the racial group. In sum, an ensemble approach that delimits a broader area of protection is inconsistent with the principle of legality, the principle of effectiveness, and the perpetrator's perception of the victim group. The four corner post-approach is flawed and therefore not ideal.

The following section gives an overview on how legal scholarship and the jurisprudence of the ad hoc ICTY and ICTR have defined the protected groups of genocide. It will reveal the great legal uncertainty that exists about the nature of human differences.

\section{Race and Legal Scholarship}

What Is Race?

There is no gene for race. There exist no genes that are shared by all members of one race and that could explain a common racial appearance; no DNA has been identified that is not also present at substantial levels in other races, thereby failing to sort individuals into different racial groups ${ }^{83}$ Instead, it has become accepted that races are social constructs rather than a biological given. ${ }^{84} \mathrm{At}$

\footnotetext{
${ }^{76}$ Nersessian, Genocide and Political Groups, 29. Moshman, “Us and Them”, 118-119.

${ }_{77}$ Moshman, "Us and Them", 120.

${ }^{78}$ Helen Klann and Phillipa McKenzie, “Judge Laïty Kama: Five Cases to Develop International Criminal Law," in From Human Rights to International Criminal Law: Studies in Honour of an African Jurist, the Late Judge Laïty Kama, ed. Emmanuel Decaux, Adama Dieng and Malick Sow (Leiden: Martinus Nijhoff Pubishers, 2007), 28.

${ }^{79}$ Fournet, Crime of Destruction, 59.

${ }^{80}$ United Nations, Report of the International Commission of Inquiry on Darfur, January 25, 2005 (UN Doc. S/2005/60), para. 494.

${ }^{81}$ Case Concerning the Territorial Dispute (Libyan Arab Jamahiriya v. Chad), ICJ Judgment (1994), 25. Similarly, a Separate Opinion to the Jelisić judgment claimed it was "a general rule of interpretation that the law must be interpreted in such a way that it has useful effect (the principle of effectiveness, or ut res magis valeat quam pereat)", The Prosecutor $v$. Jelisić, Appeals Chamber Judgment, Separate Opinion of Judge Nieto-Navia, December 14, 1999, IT-95-10-A, para. 12.

${ }^{82}$ Mark Villiger, Commentary on the 1969 Vienna Convention on the Law of Treaties (Leiden: Martinus Nijhoff Publishers, 2009), 428.

${ }^{83}$ Cosmides, Tooby and Kurzban, "Perceptions of Race", 173. Bobo, "Foreword”, x. Hoffman, "'Race' as a Legal Concept?", 1093-1159.

${ }^{84}$ United Nations Educational, Scientific and Cultural Organization (UNESCO), “Statement on Race" (1950) "For all
} 
a White House ceremony, even genome sequencer Craig Venter said: "The concept of race has no genetic or scientific basis". ${ }^{85}$ His colleague, Francis Collins further emphasized that "[t]hose who wish to draw precise racial boundaries around certain groups will not be able to use science as a legitimate justification". ${ }^{86}$

The differing physical appearance of people may be biologically heritable, yet the practical importance of what we understand as race derives from the human capacity to create and assign meanings. ${ }^{87}$ For international criminal law and the crime of genocide, the practical importance of race lies in why the victim group is targeted and whether the perpetrator believed that the victims were members of a group racially distinct from his own.

Despite the non-existence of different biologically defined human races, surprisingly many legal scholars define racial groups by means of hereditary external features, as the following examples will show. By relying on complexion, the victims of the crime of genocide are classified objectively. However, do all people with dark skin belong to the same race? Is it correct to objectively group the victims according to their appearance?

The concept of race causes difficulties to international criminal law because of the legal necessity of an objective determination of the victim's group membership. In order to achieve a conviction for the crime of genocide, the prosecution has to prove that the perpetrator targeted a national, religious, ethnical or racial group. This requirement leads courts to objectively defining race based on the victim's complexion. As long as the racial group is considered a material element of a crime, it has to be objectively determinable. As a result, international criminal courts resort to outdated ways of classifying human beings.

Instead of reverting to controversial ways of defining different human races by means externally perceptible attributes, race should be defined as the perception of a person's differentness. This subjective approach, according to which perception rather than objectively discernable characteristics are decisive, is precisely what the theory of imagined identities relies upon. Before discussing the theory of imagined identities, the next section will show how race is understood by legal scholarship.

\section{Legal Scholarship on race}

The following examples illustrate the current legal scholarship on race in international criminal law. Hans Vest refers to physical characteristics or biological ancestry when defining race, ${ }^{88}$ while Lawrence LeBlanc defines race as "associated with physical characteristics of a people such as color of skin" ${ }^{89}$ Daniel Ntanda Nsereko classifies different "racial groups (...) according to genetically transmitted differences" 190 and "[e]ach group has physical features that are hereditary [including]

practical social purposes, 'race' is not so much a biological phenomenon as social myth", in Four Statements on the Race Question, ed. UNESCO (1969), 33. The 1967 UNESCO statement confirms that "racist doctrines lack any scientific basis whatsoever" (UNESCO, "Statement on Race and Racial Prejudice of 1967," in Four Statements on the Race Question, ed. UNESCO (1969).

Even the International Haplotype Map Project, which is a multi-country effort to identify and catalogue genetic similarities and differences in human beings, states on its webpage that race was "an imprecise and mostly socially constructed category," accessed April 1, 2016. http://hapmap.ncbi.nlm.nih.gov/citinghapmap.html.

See also Banton, Racial Theories, 196. López, White by Law, 78. Schabas, Genocide in International Law, 129. Thomas Hylland Eriksen, Ethnicity and Nationalism (London: Pluto Press, 2010), 5. Erica Howard, "Race and Racism: Why does European Law have Difficulties with Definitions?" The International Journal of Comparative Labour Law and Industrial Relations (2008), 10. Davis, "Constructing Race", 7.

${ }^{85}$ Quoted in Michael Yudell, Race Unmasked: Biology and Race in the Twentieth Century (New York: Columbia University Press, 2014), 204.

${ }^{86}$ Ibid.

${ }^{87}$ Bobo, "Foreword", x. Banton, Racial Theories, 197, 212.

${ }^{88}$ Hans Vest favors a determination by means of physical characteristics or biological decent over an expansive interpretation (Hans Vest, Genozid durch organisatorische Machtapparate (Baden-Baden: Nomos, 2002), 120).

${ }^{89}$ Lawrence LeBlanc, "The United Nations Genocide Convention and political groups: should the United States propose an amendment?," Yale Journal of International Law (1998), 273.

${ }^{90}$ Daniel Ntanda Nsereko, "Genocide: a crime against mankind," in Substantive and Procedural Aspects of International Criminal Law, ed. Gabrielle Kirk McDonald and Olivia Swaak-Goldman (The Hague: Kluwer Law, 2000), 131. 
skin colour, hair, eyes and stature". ${ }^{91}$ He too refers to the genetic composition of people and relies on hereditary physical traits. Implying that race is genetically transmittable is scientifically baseless and furthermore incoherent with the current understanding of race as a social construct rather than a biological fact. ${ }^{92}$ Matthew Lippman claims that "[t]he concept of racial groups is self-evident" ${ }^{\text {"93 }}$ and Francis Boyle, agent of the state applicant in the Case on the Application of the Genocide Convention before the ICJ argues that "[t]he concepts of racial and religious groups are self-evident" ${ }^{94}$ Finally, Gerhard Werle and Florian Jessberger define a racial group as a social group whose members exhibited the same inherited, visible physical traits, such as skin colour or physical stature. ${ }^{95}$ They too rely on an objective approach, whereby people can be categorized on the basis of their features and inherited characteristics. As shown above, there is no gene for race. Race can therefore not be inherited. A reliance on heredity should consequently be avoided in defining race. This is confirmed by Michael Banton, former Chair of the Committee for the Elimination of Racial Discrimination and an authority in the studies on racial discrimination, who considers race in some cases to have no real basis in heredity whatsoever. ${ }^{96}$

The above mentioned scholarly definitions either avoid defining a racial group or relate to outdated conceptions of race, based on the wrongful understanding that there exist clearly distinguishable racial groups with distinct physical appearances and qualities. ${ }^{97}$ There is no biological foundation for race. Any kind of categorization of people by means of their features is scientifically incorrect and offensive. This raises the question of how race should be correctly defined.

\section{Different Approaches to Defining the Victim Groups of Genocide}

Art. II Genocide Convention protects four specific groups. The subjective and objective approaches to defining these protected groups rival each other. ${ }^{98}$ An objective approach relies on verifiable, hard facts. Neither the views of the victim, the perpetrator nor any third party can influence the definition of the group and the membership criteria..$^{99} \mathrm{~A}$ subjective approach is based on perception, personal opinions and interpretations. The subjective test accepts the group as defined by the perpetrator. His view becomes dispositive of the group-defining criteria. ${ }^{100}$

To objectively define a person by his or her complexion, anatomy or other physical markers, assumes that there exist different racial groups, which can be distinguished from each other by means of their appearance. ${ }^{101}$ David Nersessian rightfully concludes that there was a practical impossibility of defining groups in any way other than subjectively, namely by utilizing the perpetrator's perception. He notes that the "efforts to define protected groups objectively have

\footnotetext{
${ }^{91}$ Ibid.

${ }^{92}$ See above footnote 84 .

${ }^{93}$ Matthew Lippman, "Genocide," in International Criminal Law: Sources, Subjects, and Contents, ed. M. Cherif Bassiouni (Leiden: Martinus Nijhoff Publishers, 2008), 412.

${ }^{94}$ Case Concerning Application of the Convention on the Prevention and Punishment of the Crime of Genocide (Bosnia and Herzegovina v. Serbia and Montenegro), Supplement to the Application and to the Second Request for the Indication of Provisional Measures of Protection submitted by the Government of the Republic of Bosnia and Herzegovina, ICJ (August 22, 1993), 18.

${ }^{95}$ Gerhard Werle and Florian Jessberger, Principles of International Criminal Law (Oxford: Oxford University Press, 2014), 299. The authors do note that the concept of race was "not unproblematic given its abusive usage" (ibid.).

${ }^{96}$ Michael Banton, International Action against Racial Discrimination (Oxford: Clarendon Press, 1996), 76-82.

${ }^{97}$ The domestic US genocide legislation defines a racial group as "a set of individuals whose identity as such is distinctive in terms of physical characteristics or biological descent", thereby apparently relying on a purely objective approach (The Genocide Convention Implementation Act of 1987 [Proxmire Act], US Code § 1093, Title 18, Part 1, Chapter 50A). Michael Banton points out that the US is the only country that holds on to the practice of identifying blacks by the one-drop rule, a classification that was not applied to any other social category and unknown outside the US (Banton, Race and Ethnicity, 2). He also establishes a difference in the European and the US perspective on race (ibid., viii).

${ }^{98}$ Quayle, “Unimaginable Evil", 368.

${ }^{99}$ Nersessian, Genocide and Political Groups, 27.

${ }^{100}$ Ibid.

${ }^{101}$ Banton, Racial Theories, 198.
} 
proved largely artificial, suffer from serious analytical flaws, and in any case bear no relation to the group ultimately targeted". ${ }^{102}$

In the subjective approach, the perpetrator identifies the victim's group membership. Nevertheless, the identification of the group membership cannot completely be left to the perpetrator's imagination, because this would inevitably lead to a broadening of the exclusive victim groups of genocide. ${ }^{103}$ If the perpetrator alone defines the racial group, he could possibly perceive blue-eyed men - or women, for the sake of the argument - as a distinct race. This would conflict with the object and purpose of the Genocide Convention, which offers narrow protection to a limited number of enumerated groups.

Instead, the subjective approach has to be sufficiently specific and foreseeable in order to cohere with the principle of legality. The subsequent section outlines the theory of imagined identity, which builds on a subjective approach, and shows its relevance for the crime of genocide. Thereafter, the jurisprudence by the ad hoc international criminal tribunals on the protected groups of genocide is analyzed. The legal analysis ends with the Darfur Commission's report as well as the jurisprudence by the ICC.

\section{Imagined Identities}

Benedict Anderson (1936-2015) was a professor in political science and author of one of the most important concepts in political geography, namely that nations are "imagined communities". ${ }^{104}$ Anderson is recognized as one of the most influential scholars of his generation and his book from 1986 (revised edition 2006), Imagined Communities, is a standard work with worldwide impact across academic disciplines. ${ }^{105} \mathrm{He}$ asserts that nationalism was created by a feeling of togetherness in a nation state, despite not knowing its other members. ${ }^{106}$ This feeling was so strong that its members were willing to die for their - imagined - nation by serving the nation's army and participating in armed conflicts. ${ }^{107}$ Other scholars acknowledge that nationalism is commonly viewed as inherently irrational in the sense that it transcends considerations of self-interest. ${ }^{108}$ According to Anderson, the nation is a social construct that ties together strangers and creates a sense of togetherness, which manifests itself in language, tradition, music, literature and pride of being part of that respective nation. Importantly, nationalism is created by beliefs and felt kinship ties. The emphasis is on felt - or imagined - subjective claims. ${ }^{109}$

By applying this concept to a group of people connected to each other not by a nation, but by race, ethnicity or religion, a similar construct is created: people perceive likewise persons as similar and form groups of like-minded. Simultaneously they perceive others, outside their own group, as different. ${ }^{110}$ Although not necessarily grounded in a real, objective differentiation between the groups, this distinction is nevertheless solidified over time, thereby creating two distinct groups: "us" and "them". Ultimately, the groups are not real, but socially constructed and therefore imagined.

For the crime of genocide it is essential to pinpoint the perceptions of different identities, the "us" versus "them". This so-called othering occurs in genocide for racial groups as much as for the other protected groups. The dichotomies between us and them are emphasized, whereby the

\footnotetext{
${ }^{102}$ Ibid., 31-32.

${ }^{103}$ Ibid., 31.

${ }^{104}$ Euan Hague, "Benedict Anderson," in Key Thinkers on Space and Place, ed. Phil Hubbard and Rob Kitchin (London: Sage Publications, 2011), 16.

${ }^{105}$ Ibid., 17-19.

${ }^{106}$ Anderson, Imagined Communities, 6 and 26.

${ }^{107}$ Anderson, Imagined Communities, 7. Also recognized by Russell Hardin, One for All: The Logic of Group Conflict (Princeton: Princeton University Press, 1995), 150.

${ }^{108}$ Hardin, One for All, 46.

${ }^{109}$ Ibid., 147.

${ }^{110}$ Guglielmo Verdirame, "The Genocide Definition in the Jurisprudence of the ad hoc Tribunals," International and Comparative Law Quarterly (2000), 592.
} 
image of the "others" is created, often parallel to creating a new sense of "self". ${ }^{111}$ Of significance to any genocidal process is the stigmatization of the others as the out-group: they are seen as inferior, but simultaneously present a threat to the in-group. ${ }^{112}$ Any genocide is preceded by a process of creation of identities, with the aim of destroying the identity and ultimately the existence of the others. ${ }^{113}$ Gradually, the othering and stigmatization becomes a socially accepted way of perceiving outsiders to one's own group. This process is demonstrated in the following examples.

The case of Rwanda exemplarily shows that the Hutu and Tutsi were very similar groups, largely sharing the same nationality, religion, language and traditions. ${ }^{114}$ The German and later the Belgian colonizers perceived the Tutsi to be more like them in height and color and established the Tutsi as the indigenous elite. ${ }^{115}$ A Belgian law of 1931 determined that whoever owned more than ten cows was a Tutsi and thereby created a wealth-based system of division. ${ }^{116}$ The introduction of identity cards during Belgian colonialism consolidated the membership to the Tutsi, Hutu or Twa group and simultaneously implanted the vision of Tutsi superiority; the membership to one of the three groups was therefore primarily a result of a social attribution process. ${ }^{117}$ Jan Pronk names Rwanda as an example of imagined communities due to the imagined physical and mental superiority of the Tutsi and the inferiority of the Hutu. ${ }^{118}$ Payam Akhavan furthermore emphasizes that the distinction of Hutu and Tutsi "was born of racialist mythology, gradually assumed a socially constructed reality, and ultimately defined the population slated for extermination". ${ }^{119}$ The different groups were constructed as a collective imaginary, as social constructs rather than objectively defined groups. ${ }^{120}$

The propaganda preceding the genocide in Rwanda was based on the Hutu's feeling of inferiority and found its valve in a reversing of positions: the Tutsi, who were imagined as superior to the Hutu, were inferiorated by means of hate speech, termed "cockroaches" and ultimately targeted for extermination. ${ }^{121}$ The Tutsi were portrayed as the enemy from within that needed to be stopped before it swallowed the suppressed Hutu culture. ${ }^{122}$ This imagined fear of the other manifested itself in the official propaganda and

${ }^{111}$ Anthonie Holslag, "The Process of Othering from the 'Social Imaginaire' to Physical Acts: An Anthropological Approach," Genocide Studies and Prevention: An International Journal 9 (2015), 96. Chalk and Jonassohn, History and Sociology of Genocide, 28.

${ }^{112}$ Laban Hinton, "Dark Side of Modernity", 6 and 13.

${ }^{113}$ Chalk and Jonassohn, History and Sociology of Genocide, 28, 30. Mark Kielsgard, Responding to Modern Genocide: At the Confluence of Law and Politics (Abingdon: Routledge, 2016), 77-79.

${ }^{114}$ In the words of anthropologist Alex de Wall: "[I]t is rarely possible to tell whether an individual is a Twa, Hutu, or Tutsi (...) from his or her height. Speaking the same language, sharing the same culture and religion, living in the same places, they are in no sense 'tribes', nor even distinct 'ethnic groups"', Alex De Waal, "Genocide in Rwanda," Anthropology (1994), 1-2 (emphasis in original). Gregory Stanton also notes that the Hutu and Tutsi shared the same language, culture and religion (Gregory Stanton, “Could the Rwandan Genocide Have Been Prevented?," Journal of Genocide Research (2004), 213).

115 The Prosecutor v. Akayesu, Trial Chamber Judgment, September 2, 1998, ICTR-96-4-T, para. 82. Payam Akhavan, “The Crime of Genocide in the ICTR Jurisprudence", Journal of International Criminal Justice (2005), 1000. Beth Van Schaack, "Darfur and the Rhetoric of Genocide," Whittier Law Review 26 (2005), 1120. Amann, "Group Mentality", 103.

${ }^{116}$ Agnieszka Szpak, “National, Ethnic, Racial, and Religious Groups Protected against Genocide in the Jurisprudence of the Ad Hoc International Criminal Tribunals," European Journal of International Law 23 (2012), 160.

${ }^{117}$ Laban Hinton, "Dark Side of Modernity", 16. Amann, Diane, "Prosecutor v. Akayesu," American Journal of International Law 93 (1999), 195. Alex De Waal, "Group Identity, Rationality, and the State," Critical Review 11 (1997), 287. De Waal notes that the Twa as hunter-gatherers and potters remained outside the Hutu-Tutsi dynamic, given the lowest social position of all, namely as 'remnants of an earlier stage of human evolution' (ibid., 286).

${ }^{118}$ Jan Pronk, “The United Nations After 50 Years," in Contemporary Genocides: Causes, Cases, Consequences, ed. Albert Jongman (Leiden: PIOOM, 1996), xi.

${ }^{119}$ Akhavan, "The Crime of Genocide", 1000.

${ }^{120}$ David Deutsch and Niza Yanay, "The Politics of Intimacy: Nazi and Hutu Propaganda as Case Studies," Journal of Genocide Research 18 (2016), 31.

${ }^{121}$ Mark Drumbl, Atrocity, Punishment, and International Law (Cambridge: Cambridge University Press, 2007), 41. The Prosecutor v. Ruggiu, Amended Indictment, December 18, 1998, ICTR-97-32, 6-7.

${ }^{122}$ Holslag, "Process of Othering", 102. Laban Hinton, "Dark Side of Modernity", 16 and 20. 
eventually also the personal rhetoric, often reverting to diminutive and dehumanizing language. ${ }^{123}$

A reverse development happened in the Balkans in the early 1990s. The collapse of the League of Communists in 1990 and the interconnected disintegration of Yugoslavia into its warring factions marked the end of a common Yugoslav national identity. The imagined community of Yugoslavia became unimaginable from 1991-1992 onwards. ${ }^{124}$ For example, the Serbs in Croatia identified themselves for decades as Yugoslavs. Due to the events in the early 1990s, however, they started perceiving themselves as Serbs in Croatia instead of under the former common denominator of Yugoslavs. ${ }^{125}$ Socially relevant groups were created that perceived each other as distinct. Similarly to Rwanda, the dichotomization led to an identification of us versus them.

The theory of imagined identities was for the first time applied to international criminal law in the 2005 Report by the Darfur Commission. The Darfur report will be analyzed more in depth in the following section. With reference to a scholarly article by Guglielmo Verdirame, the Commission emphasized that "collective identities (...) are by their very nature social constructs, 'imagined' identities entirely dependent on variable and contingent perceptions, and not social facts" ${ }^{126}$ While the idea of imagined, as opposed to factual or real, identities is appealing because it avoids any objective definition of the protected group, it nevertheless has to be coherent with the principle of strict legality. The theory of imagined identities, which builds on a subjective approach to group membership, cannot go beyond the narrow definition of Art. II Genocide Convention and cannot render invalid the principle of foreseeability and specificity. The imagination of the perpetrator can, in other words, not exceed the Genocide Convention's understanding of the protected victim groups.

The current understanding of race as a subjective and social concept, with the perception of the perpetrator as the key element, points to the application of the theory of imagined identities in praxis. The perpetrator perceives a victim as belonging to a different group, which he imagines having different and inferior attributes and qualities. This imagined inferiority then gives the perpetrator, in his eyes, a justification to discriminate and ultimately to exterminate this imaginary group. The identity of the others and their differences to us is passed on from one generation to the next by means of narratives. These accounts formulate and solidify the conception of the others' personhood and thereby their identity. ${ }^{127}$

Such historical and sociological narratives harden prejudices about the victims: the others have "always" been different, they have "never" been part of the society at large, but have "persistently" chosen to remain in their own community. The imagined social construct of two different groups becomes a reality as soon as it is effective. This effectiveness is demonstrated in that the in-group treats the out-group (the others) as real. In doing so, the creation of a social reality is revealed that eventually entails social and/or legal consequences. This formation of an imagined identity is in itself not further disquieting. However, if the effectiveness results in stigmatization, inferiorization, dehumanization and ultimately the aim of destruction, the risk of genocide is imminent. ${ }^{128}$

The example of Rwanda shows this development clearly: prior to the colonialization, the Hutu and Tutsi group membership was fluid and unsettled: wealth enabled ascension of the social

\footnotetext{
${ }^{123}$ Deutsch and Yanay, "Politics of Intimacy", 22.

${ }^{124}$ Robert Hayden, "Imagined Communities and Real Victims: Self-Determination and Ethnic Cleansing in Yugoslavia," in Genocide: An Anthropological Reader, ed. Alexander Laban Hinton (Malden: Blackwell Publishers, 2002), 236-237. Hardin, One for All, 156-163.

${ }^{125}$ Hayden, "Imagined Communities", 233. Banton, Racial Theories, 210.

${ }^{126}$ United Nations, Report of the International Commission of Inquiry on Darfur to the United Nations Secretary-General (hereafter: Darfur Report), January 25, 2005 (UN Doc. S/2005/60), para. 499 (emphasis in original) with reference to Verdirame, "The Genocide Definition", 592.

${ }^{127}$ Anderson, Imagined Communities, 204-205.

${ }^{128}$ Gregory Stanton, Countries at Risk Report 2012 (Washington: Genocide Watch, 2012). The report includes a list of eight stages of genocide, which was based on a 1996-model. In 2013, Stanton presented a ten stage model, describing amongst others the stages of stigmatization ("classification" and "symbolization"), inferiorization ("discrimination"), dehumanization and destruction ("extermination"), accessed April 11, 2016. http://www.genocidewatch.org/genocide/ tenstagesofgenocide.html.
} 
ladder from being a (poor) Hutu to being a (wealthy) Tutsi. Intermarriage between the groups was common. ${ }^{129}$ The introduction of identity cards by the Belgium colonizers changed the picture drastically: group membership became more or less permanent and immutable. A person's identity was defined in one of the three categories (Hutu, Tutsi and Twa) and considered innate by means of patrilineal heredity of ethnicity. ${ }^{130}$ The colonial masters created and imposed a largely imaginary system of group membership. This system of identification became unalterable, operational and therefore also effective once the Hutu, Tutsi and Twa started using their ID-cards.

Race, ethnicity, nationality and religion become operational concepts of group membership once an effective system has been put into place. Whether imagined systems are founded on fictional or real grounds is irrelevant: distinct groups are created and thereby objectified. Thus, effectiveness and operationability determine the membership to a racial, ethnical, national or religious group. Or in other words: once a group membership is operational, it becomes effective and real.

The next section will analyze selected examples of case law by the ad hoc international criminal tribunals as well as the Darfur Commission's report. It will reveal that jurisprudence has gradually shifted from defining the victim groups objectively to defining them subjectively, based primarily upon the perception of the perpetrator. It will in particular show that the Darfur Commission applied the theory of imagined identity. The jurisprudence of the ICC on the situation of Darfur, which largely builds upon the Darfur Commission's report, will also be analyzed. The ICC's initial steps in dealing with the crime of genocide in the situation of Darfur will provide an outlook on future developments in the definition of the protected groups.

\section{Race in International Criminal Jurisprudence}

The interpretation by the international criminal tribunals of the crime of genocide and the protected groups are far from specific or foreseeable. While this is true for all of the four protected groups, it is particularly significant for the racial group. As such, the tribunals' judgments might challenge the principle of legality. For future cases it is important that the tribunals fully recognize and respect legal certainty and predictability in their interpretation of the protected groups of genocide. ${ }^{131}$

The jurisprudence of the ICTR and the ICTY on the group definition is incoherent because it varies in its approach to defining the protected groups. Early cases took a primarily objective approach, while later cases increasingly relied on the perpetrator's perception of the victim group, thus applying a subjective approach. The following examples reveal the inconsistency of the judicial approaches.

\section{ICTR Jurisprudence}

The ICTR produced the first case law on the crime of genocide and in particular the racial group. In the first ever genocide trial in history, The Prosecutor v. Akayesu, the Trial Chamber defined a racial group as follows: "The conventional definition of racial group is based on the hereditary physical traits often identified with a geographical region, irrespective of linguistic, cultural, national or religious factors" ${ }^{132}$ The Trial Chamber did not cite any authority for its definition. This primarily objective approach to a racial group is ambiguous since it refers to heredity and implies an identification of group members by means of their genetically defined physical traits. As shown earlier, a reference to heredity preserves an outdated and contentious method of classifying people. The Trial Chamber, however, weakened its statement by referring to "the conventional definition",

\footnotetext{
${ }^{129}$ Lyal Sunga, The Emerging System of International Criminal Law: Developments in Codification and Implementation (The Hague, Kluwer Law International, 2010), 112. Scott Straus, The Order of Genocide (Ithaca: Cornell University Press, 2006), 20-21.

${ }^{130}$ The Prosecutor v. Akayesu, Trial Chamber Judgment, September 2, 1998, ICTR-96-4-T, para. 171. The Prosecutor v. Kayishema and Ruzindana, Trial Chamber Judgment, May 21, 1999, ICTR-95-1-T, para. 523. United Nations, Preliminary Report of the Independent Commission of Experts Established in Accordance with Security Council Resolution 935 (1994), October 4, 1994 (UN Doc. S/1994/1125 (1994), Annex), para. 45.

${ }^{131}$ Caroline Fournet, "The Actus Reus of Genocide," in Elements of Genocide, ed. Paul Behrens and Ralph Henham (Abingdon: Routledge, 2013), 57-58.

132 The Prosecutor v. Akayesu, Trial Chamber Judgment, September 2, 1998, ICTR-96-4-T, paras. 514 and 516.
} 
yet without determining its accuracy. The judges remained silent on what is considered a nonconventional definition of race.

Furthermore, the judgment mentions the identification of these traits with a geographical region. The Trial Chamber thereby partially resorts to a subjective approach, whereby the term "identified" points to the perpetrator's perception of the victim group's racial affiliation to its geographical location or origin. In Akayesu, the ICTR defined race foremost by heredity. Hereditary physical traits are objective, factual elements. The approach taken by the Trial Chamber is therefore foremost an objective one. ${ }^{133}$ However, it also noted that these hereditary traits were often identified with a geographical region. The word "often" indicates an ordinary, but not exclusive approach to defining race. The word "identity" clearly connects to a person's perception, thus a subjective act. The overall approach taken by the ICTR is therefore a primarily objective approach with certain subjective elements. ${ }^{134}$

Only one year after the Akayesu trial judgment, the same bench of judges rendered the trial judgment against Georges Anderson Nderubumwe Rutaganda. It pronounced a more balanced definition of the victim group by stating that the membership was a subjective rather than an objective concept. ${ }^{135}$ The Tribunal in case further held that the "victim is perceived by the perpetrator of genocide as belonging to a group slated for destruction. In some instances, the victim may perceive himself/ herself as belonging to the said group". ${ }^{136}$ By emphasizing perception, Rutaganda took a subjective approach and shifted away from the primarily objective approach taken in Akayesu. ${ }^{137}$

The ICTR Bagilishema trial judgment of 2001 demonstrated the difficulties of an objective group definition. It held that, although indicative definitions of these four terms have been provided,

the concepts of national, ethnical, racial, and religious groups enjoy no generally or internationally accepted definition. Each of these concepts must be assessed in the light of a particular political, social, historical, and cultural context. Although membership of the targeted group must be an objective feature of the society in question, there is also a subjective dimension. ${ }^{138}$

Here, in a footnote, the Trial Chamber refers to the above-mentioned report by the Commission of Experts on Rwanda and its statement that "to recognise that there exists discrimination on racial or ethnic grounds, it is not necessary to presume or posit the existence of race or ethnicity itself as a scientifically objective fact". ${ }^{139}$ The judgment further reads:

A group may not have precisely defined boundaries (...). Moreover, the perpetrators of genocide may characterize the targeted group in ways that do not fully correspond to conceptions of the group shared generally, or by other segments of society. In such a case (...) if a victim was perceived by a perpetrator as belonging to a protected group, the victim could be considered by the Chamber as a member of the protected group, for the purposes of genocide. ${ }^{140}$

\footnotetext{
${ }^{133}$ Matthias Schuster, "The Crime of Genocide Applied in Practice: Selected Aspects of the Jurisprudence of the Ad Hoc Tribunals' Appeals Chambers," in The Genocide Convention Sixty Years After its Adoption, ed. Christoph Safferling and Eckart Conze (The Hague: TMC Asser Press, 2010), 216.

${ }^{134}$ Ibid., 217.

${ }^{135}$ The Prosecutor v. Rutaganda, Trial Chamber Judgment, December 6, 1999, ICTR-96-3-T, , para. 56.

${ }^{136} \mathrm{Ibid}$. The Kamuhanda and Kajelijeli judgments contain a similar wording, however, they base their subjective approach on the perpetrator's perception only (The Prosecutor v. Kamuhanda, Trial Chamber Judgment, January 22, 2004, ICTR99-54A-T, para. 630; The Prosecutor v. Kajelijeli, Appeals Chamber Judgment, December 1, 2003, ICTR-98-44A, para. 811).

${ }^{137}$ Verdirame, "The Genocide Definition", 592 and 594.

${ }^{138}$ The Prosecutor v. Bagilishema, Trial Chamber Judgment, June 7, 2001, ICTR-95-1A-T, para. 65.

${ }^{139} \mathrm{Ibid}$., para. 65 with reference to United Nations, Final Report of the Commission of Experts, para. 159.

${ }^{140}$ The Prosecutor v. Bagilishema, Trial Chamber Judgment, June 7, 2001, ICTR-95-1A-T, para. 65.
} 
In the Bagilishema trial judgment, the ICTR took a purely subjective approach to defining all the victim groups of genocide, including the racial group. The perpetrator's perception of the victims' group membership was crucial: he intended to destroy them because of their perceived or real group membership, irrespective of how the group is conceived by other segments of society. In sum, the Bagilishema trial judgment took a primarily subjective approach with some objective elements and as such further consolidated the innovative, subjective definition of group membership. ${ }^{141}$ According to Barbara Lüders, Bagilishema was the turning point in the ICTR's jurisprudence from an objective to a subjective approach. ${ }^{142}$ The fact that the Kayishema and Ruzindana trial judgment of 1999 laid the groundwork for a subjective approach challenges this opinion. ${ }^{143}$ The Kayishema and Ruzindana judgment defined an ethnic group as one "whose members share a common language and culture; or, a group which distinguishes itself, as such (self identification); or, a group identified as such by others, including perpetrators of the crimes (identification of others)" ${ }^{144}$ Apparently inspired by the Akayesu trial judgment, it defined the racial group as follows: "a racial group is based on hereditary physical traits often identified with geography" ${ }^{145}$ While the Trial Chamber subjectively defined the ethnical group by means of self-identification or identification of others, it defined the racial group objectively.

The ICTR Appeals Chamber has not often dealt with the definition of the protected groups of genocide. On one rare occasion, the Appeals Chamber in Nahimana et al. recognized the application of a subjective approach: "[T]he jurisprudence of the ad hoc Tribunals acknowledges that the perception of the perpetrators of the crimes may in some circumstance be taken into account for the purposes of determining membership of a protected group" ${ }^{146}$ It decided that the attacks on Hutu political opponents were not acts of genocide because the victims were acknowledged as such and not perceived as Tutsi. ${ }^{147}$

In 2000, the ICTR in Semanza declared the division of the Rwandan population into three ethnical groups a fact of common knowledge. ${ }^{148}$ Declaring a fact common knowledge removes it from being a subject to dispute and includes it into a list of common or universally known historical, geographical facts, or the laws of nature, such as the days of the week. ${ }^{149}$ According to the Tribunal, common knowledge also covered those facts that were generally known within a tribunal's territorial jurisdiction. ${ }^{150}$ The consequence of declaring the ethnic grouping as a fact of common knowledge is that no further proof is necessary, since the existence of the Tutsi group as a protected ethnic group is determined. ${ }^{151}$ Although the Trial Chamber emphasized that it could not "take judicial notice of matters, which are unadorned legal conclusions", 152 it in effect evaded

${ }^{141}$ Interestingly, in the ICJ Case Concerning Application of Genocide Convention (Bosnia and Herzegovina v. Serbia and Montenegro), the legal representative of Serbia and Montenegro claimed that the ICTR in Bagilishema had adopted an exclusively objective approach. According to the representative, the ICTR concluded that the group membership should be an objective element of society in question. The legal counsel thereby disregarded that Bagilishema dealt with the perpetrator's perception of the protected group, hence taking into account the subjective elements in defining a group membership (Case Concerning Application of Genocide Convention, Document No. CR 2006/43, Public Sitting (May 8, 2006), 36-37).

${ }^{142}$ Barbara Lüders, Die Strafbarkeit von Völkermord nach dem Römischen Statut für den Internationalen Strafgerichtshof (Berlin: Berliner Wissenschafts-Verlag, 2004), 57.

${ }^{143}$ The Prosecutor v. Kayishema and Ruzindana, Trial Chamber Judgment, May, 21, 1999, ICTR-95-1-T, para. 98.

${ }^{144}$ Ibid., para. 98.

${ }^{145}$ Ibid.

${ }^{146}$ The Prosecutor v. Nahimana et al., Appeals Chamber Judgment, November 28, 2007, ICTR-99-52-A, para. 496.

${ }^{147}$ Ibid.

${ }^{148}$ The Prosecutor v. Semanza, Decision on the Prosecutor's Motion for Judicial Notice and Presumption of Facts Pursuant to Rules 94 and 54, November 3, 2000, ICTR-97-20-T, paras. 23, 29, 48(b) and Annex A.

${ }^{149}$ Mark Klamberg, Evidence in International Criminal Trials: Confronting Legal Gaps and the Reconstruction of Disputed Events (Leiden: Martinus Nijhoff Publishers, 2013), 472.

${ }^{150}$ The Prosecutor v. Semanza, Decision on the Prosecutor's Motion for Judicial Notice and Presumption of Facts Pursuant to Rules 94 and 54, November 3, 2000, ICTR-97-20-T, para. 23.

${ }^{151}$ Schuster, "The Crime of Genocide", 220.

152 The Prosecutor v. Semanza, Decision on the Prosecutor's Motion for Judicial Notice and Presumption of Facts Pursuant to Rules 94 and 54, November 3, 2000, ICTR-97-20-T, para. 35. This decision was confirmed by the Appeals Chamber: The 
any further discussion on the ethnicity of the involved groups and hindered further elaboration on the victim groups of the Rwandan genocide. The ICTR Appeals Chamber also took notice of the genocide in Rwanda against the Tutsi ethnic group, thereby accepting as common knowledge the existence of the Tutsi as a protected group. ${ }^{153}$ Matthias Schuster laments that the appellate bodies of the ad hoc tribunals did not clarify "the law on such a central element of the definition of the crime of genocide". ${ }^{154}$

\section{ICTY Jurisprudence}

In May 1993, acting under Chapter VII of UN Charter, the UN established the ICTY in response to mass atrocities then taking place in Croatia and Bosnia and Herzegovina. ${ }^{155}$ The ICTY was the first international war crimes tribunal since the Nuremberg and Tokyo Tribunals following the Second World War. In one of the Tribunal's most important cases, the Jelisić judgment, the Trial Chamber acknowledged that an objective approach to defining the victim group of genocide was a risky undertaking:

to define a... racial group today using objective and scientifically irreproachable criteria would be a perilous exercise whose result would not necessarily correspond to the perception of the persons concerned by such categorisation. Therefore, it is more appropriate to evaluate the status of a... racial group from the point of view of those persons who wish to single that group out from the rest of the community. The Trial Chamber consequently elects to evaluate membership in a... racial group using a subjective criterion. ${ }^{156}$

At first sight the Jelisić judgment seemed to allow a victim- as well as a perpetrator-based approach ("perception of the persons concerned by such categorization"). However, the consecutive sentence makes clear that the perpetrator alone defines the victim group ("point of view of those persons who wish to single that group out"). The judgment correctly recognized that it was applying a subjective approach.

The Trial Chamber in the judgment against Radoslav Brđanin took a slightly different subjective approach by holding that the victim group "may be identified by means of the subjective criterion of the stigmatization of the group, notably by the perpetrators of the crime, on the basis of its perceived... racial... characteristics. In some instances, the victim may perceive himself or herself to belong to the aforesaid group" ${ }^{157}$ This judgment provided two possibilities to defining the protected groups, namely either a perpetrator- or a victim-based approach. The wording "notably by the perpetrators" reveals a primacy of a perpetrator-based approach, which is further confirmed in that "in some instances, the victim may perceive himself or herself to belong to the aforesaid group". As a rule, the tribunal seemed to rely on the perpetrator's perception. Occasionally, however, also the victim's perception could influence the group definition. The judges nevertheless demanded objective criteria, without indicating their scope, in holding that "the correct determination of the relevant protected group has to be made on a case-by-case basis, consulting both objective and subjective criteria. This is so because subjective criteria alone may not be sufficient to determine the group targeted for destruction and protected by the Genocide Convention". ${ }^{158}$ The Trial Chamber acknowledged that a subjective approach alone could cause an inadmissible broadening of the protected groups, which would conflict with the principle of strict legality and foreseeability. However, the judges did not recognize the possibility of relying on a subjective approach that builds on the theory of imagined identities. According to that theory,

\footnotetext{
Prosecutor v. Semanza, Appeals Chamber Judgment, May 20, 2005, ICTR-97-20-A, para. 192.

${ }^{153}$ The Prosecutor v. Karemera et al., Decision on the Prosecutor's Interlocutory Appeal of Decision on Judicial Notice, June 16, 2006, ICTR-98-44-AR73, paras. 33-38.

${ }^{154}$ Schuster, "The Crime of Genocide", 220.

${ }^{155}$ Established by Security Council Resolution S/RES/827 (25 May 1993).

156 The Prosecutor v. Jelisić, Appeals Chamber Judgment, December 14, 1999, IT-95-10-A, para. 70.

${ }^{157}$ The Prosecutor v. Brđanin, Trial Chamber Judgment, September 1, 2004, IT-99-36-T, para. 683.

${ }^{158}$ Ibid., para. 684.
} 
the prosecutor would have to prove that the perpetrator perceived the victim group as belonging to a group racially distinct from his own and therefore targets its members with the intention of destroying them.

The ICTY jurisprudence, similarly to that of the ICTR, reveals a gradual shift from an objective to a more subjective approach in defining the protected groups of genocide. Nevertheless, neither ad hoc tribunal ever took a purely subjective approach and always required some objectively definable components, however without sketching out their contours.

Apart from the jurisprudence by the two trial chambers of the ad hoc tribunals, there has been limited case law on the international level defining the protected groups of genocide. This article will not examine the jurisprudence of the Nuremberg or Tokyo Tribunals, the ECCC, the Special Panels of the Dili District Court, the Special Tribunal for Lebanon or the Special Court for Sierra Leone, some of which do not even have subject-matter jurisdiction over the crime of genocide. However, the Commission of Inquiry on Darfur comprehensively dealt with the definition of the protected groups and referred to imagined identities. Its report is therefore of particular interest for the further analysis.

\section{Report by the Darfur Commission}

In 2004, a UN Security Council resolution requested the establishment of the Darfur Commission. Its tasks were to immediately investigate reports of violations of international law in Darfur, to determine whether acts of genocide had occurred, and to identify the perpetrators of such violations. ${ }^{159}$ As a Commission of Inquiry, the Darfur Commission was not a judicial organ. However, it was headed by renowned ICTY Judge and Professor of Law Antonio Cassese and was mandated to make a legal assessment of the situation in Darfur. The Commission produced a comprehensive quasi-legal report that resembles a trial judgment, but was not legally binding. ${ }^{160}$ The report notes that although "it is not a judicial body... the Commission adopted an approach proper to a judicial body". ${ }^{161}$ The methods applied and the analysis performed were undoubtedly of a legal character.

The Commission was challenged by the fact that crimes were committed against different tribal groups (chiefly the Fur, Masalit and Zaghawa tribes) that did not appear to make up ethnic groups distinct from the ethnic group to which the attackers belonged. ${ }^{162}$ The Commission found that the tribes who supported the insurgents were increasingly perceived as African, while those supporting the government were perceived as Arabs, even though there were no objective grounds for such distinctions, since both groups shared the same faith and spoke the same language. ${ }^{163}$ The rift between the tribes, and the political polarization around the rebel opposition to the central authorities, coupled with the growing insistence of some circles and the media on such an ArabAfrican divide, contributed to "the consolidation of the contrast and gradually created a marked polarization in the perception and self-perception of the groups concerned". ${ }^{164}$

The Darfur Commission determined that the formation process of perceiving another group as distinct usually originated in historical and social grounds. The others were perceived as making up a different and opposed group. The process "gradually hardens and crystallizes into a real and factual opposition. It thus leads to an objective contrast" ${ }^{165}$ Despite originating in perception, the groups eventually became objectively distinguishable groups. ${ }^{166}$ Thereby the Darfur Commission seemingly added an additional category to the existing objective and subjective approaches in

\footnotetext{
${ }^{159}$ UN Doc. S/RES/1564 (September 18, 2004), para. 12.

${ }^{160}$ Darfur Report, UN Doc. S/2005/60 (January 25, 2005).

${ }^{161}$ Darfur Report, para. 14.

162 Ibid., para. 508.

${ }^{163}$ Ibid., paras. 508 and 509. While there might be other markers, the Commission explicitly mentions religion and language.

${ }^{164}$ Ibid., para. 509.

${ }^{165}$ Ibid., para. 500

${ }^{166}$ Ibid., para. 500.
} 
defining the victim groups of genocide, namely an objectified subjective approach. ${ }^{167}$ According to that approach, an initially subjective view of a group's differentness becomes objective in the course of time if it is passed on from one generation to the next. It is, however, unclear how much time would have to pass in order for an objectified approach to occur. The Darfur Report does not answer this question. It could be assumed that a subjective perception could become objectified in the course of a generation, perhaps an even shorter period of time.

Not only did the Darfur Commission construct a new approach to defining the protected groups of genocide, it also mentioned imagined identities:

the approach taken to determine whether a group is a (fully) protected one has evolved from an objective to a subjective standard to take into account that collective identities... are by their very nature social constructs, 'imagined' identities entirely dependent on variable and contingent perceptions, and not social facts, which are verifiable in the same manner as natural phenomena or physical facts. ${ }^{168}$

The Darfur Commission finds that the protected groups of genocide are social constructs rather than social facts. Essentially, the victim groups are imagined identities based on the perception of their differentness. In its essence, the Darfur Report describes the phenomenon of othering, which has been mentioned above. In the case of Darfur, the process of othering was revealed by the creation of the binaries of Arab and African tribes, the latter being portrayed as inferior. The Commission found that a growing polarization of identities increasingly led to a consolidation of the contrasts between the tribes. ${ }^{169}$ Eventually, the concerned tribes perceived themselves as either African or Arab and began making up distinct groups. Derogatory epithets with the intention of stigmatizing, inferiorating and ultimately dehumanizing the others further intensified the othering. ${ }^{170}$ John Hagan and Wenona Rymond-Richmond recognized that "[i]t was when the imposed meaning of race by others became more starkly binary and stigmatic, separating 'us' from 'them', that genocide could begin. When President al-Bashir [of Sudan] collectively identified the selected groups as 'Zourga', he opened a door to stigmatization and violence."171

In sum, the Darfur Commission applied an objectified subjective approach and considered the process of othering. Most importantly, the Commission acknowledged the concept of imagined identities as a basis to define the protected groups of genocide. It thereby took a giant leap in defining the victim groups and translated the process of othering into a valid legal consideration. In doing so, the Commission recognized the importance of social processes, irrespective of their objective recognition. Genocide is precisely about the creation of identities, the stigmatization and dehumanization of the victim group, defined by the perpetrator only. In acknowledging the legal importance of social constructs, the Darfur Commission provided for a legally sound definition of, amongst others, the racial group. Whether the racial group has an objective existence is, according to this innovative approach, not important, as long as the perpetrator perceives the group as racially distinct from his own and treats it inferiorly, with the ultimate aim of destroying it.

\section{ICC Jurisprudence}

In March 2005, the UN Security Council referred the situation in Darfur to the ICC Prosecutor because it continued to constitute a threat to international peace and security. ${ }^{172}$ The referral was to a large extent based on the findings of the Darfur Commission. Subsequently, the Prosecutor opened an investigation against the sitting President of Sudan and Commander-in-Chief of the Sudanese Armed Forces, Omar Hassan Ahmad al-Bashir, and issued two arrest warrants in 2009

\footnotetext{
${ }^{167}$ Nersessian, Genocide and Political Groups, 32.

${ }^{168}$ Darfur Report, para. 499 (emphasis in original).

${ }^{169}$ Ibid., para. 510.

${ }^{170}$ Ibid., para. 511.

${ }^{171}$ John Hagan and Wenona Rymond-Richmond, Darfur and the Crime of Genocide (Cambridge: Cambridge University Press, 2009), xxii (emphasis added).

172 UN Doc. S/RES/1593 (2005) of 31 March 2005.
} 
and 2010, respectively, listing ten counts of crimes against humanity, war crimes and genocide. ${ }^{173}$ With regard to the crime of genocide, the judges of the Pre-Trial Chamber found that the three targeted tribes of the Fur, Masalit and Zaghawa, appeared all to have "Sudanese nationality, similar racial features, and a shared Muslim religion". ${ }^{174}$ They could therefore not be classified as different national, racial or religious groups. The judges discussed whether the three tribes were distinct ethnicities, which was answered affirmatively "as there are reasonable grounds to believe that each of the groups... has its own language, its own tribal customs and its own traditional links to its lands".${ }^{175}$ With reference to the ICJ judgment on the Case Concerning the Application of the Convention on the Prevention and Punishment of the Crime of Genocide (Bosnia and Herzegovina v. Serbia and Montenegro) of 26 February 2007, the majority judges refrained from further exploring the issue of "whether a wholly objective (based on anthropological considerations), a wholly subjective (based only upon the perception of the perpetrators), or a combined objective/subjective approach" 176 should be adopted, because they considered it unnecessary to further explore this issue for the purpose of the decision. ${ }^{177}$

Despite the lack of clarification by the majority, the dissenting opinion by Judge Ušacka promises further debate about the concept and contours of protected groups. ${ }^{178}$ Referring to the jurisprudence by the ad hoc tribunals, she noted that subjective criteria, like the stigmatization of the group by the perpetrators, as well as objective criteria, like the particulars of a given social or historical context, had to be considered in the definition of the protected groups of genocide. ${ }^{179}$ Judge Ušacka dissented in the classification of the targeted groups as three distinct ethnicities. Instead, she suggested to define the protected group as a single ethnic group of the "African tribes", since all three groups were a "perceived unitary entity, which is in turn comprised of smaller groups, including the Fur, Masalit and Zaghawa". ${ }^{180}$ It is interesting that Judge Ušacka defines the victim groups as tribes, while the Darfur Commission determined that tribes were not a protected group of the crime of genocide, unless they also constituted a distinct racial, national, ethnical or religious group. ${ }^{181}$ However, Judge Ušacka's classification coheres with the International Law Commission (ILC) and its Draft Code of Crimes of 1996, according to which genocide covered acts committed against members of a tribal group. ${ }^{182}$ Of significance to the discussion on imagined identities is the fact that the majority in the Omar Al-Bashir decision recognized the different approaches of defining the protected groups of genocide, but did not want to position itself, whereas Judge Ušacka clearly relied on perception and thereby a wholly subjective approach.

Recent jurisdiction by the ICC reveals a continued trend of relying on perception rather than objective, factual realities. In the Bosco Ntaganda case, which dealt with war crimes rather than genocide, the ICC repeatedly mentioned the notion of perception. For example, it referred to victims "perceived to be non-Itema", 183 "those perceived to be non-originaires"184 or an attack

\footnotetext{
${ }^{173}$ Following an appeal by the Prosecutor against the decision by the Pre-Trial Chamber I not to include genocide into the first warrant of arrest, genocide was included into the counts and a second arrest warrant issued. Accessed May 26, 2016, http://www.icc-cpi.int/iccdocs/PIDS/publications/AlBashirEng.pdf.

${ }^{174}$ The Prosecutor v. Al-Bashir, Decision on the Prosecution's Application for a Warrant of Arrest against Omar Al-Bashir, March 4, 2009, ICC-02/05-01/09, para. 136.

175 Ibid., para. 137.

${ }^{176}$ Ibid., p. 48, footnote 152.

177 Ibid.

${ }^{178}$ Ibid., Separate and Partly Dissenting Opinion of Judge Anita Ušacka, paras. 24-26. Fanny Martin, "The Notion of 'Protected Group' in the Genocide Convention and its Application," in The UN Genocide Convention: A Commentary, ed. Paola Gaeta (Oxford: Oxford University Press, 2009), 127.

${ }^{179}$ The Prosecutor v. Al-Bashir, Separate and Partly Dissenting Opinion of Judge Anita Ušacka, para. 23.

${ }^{180}$ Ibid., paras. 25-26.

${ }^{181}$ Darfur Report, para. 496.

${ }^{182}$ ILC, Report on the work of its forty-eighth session (UN Doc. A/51/10, 45), commentary 9.

${ }^{183}$ The Prosecutor v. Bosco Ntaganda, Decision Pursuant to Article 61(7)(a) and (b) of the Rome Statute on the Charges of the Prosecutor Against Bosco Ntaganda, June 9, 2014, ICC-01/04-02/06, para. 19.

${ }^{184}$ Ibid.
} 
on "those perceived to belong to ethnic groups". ${ }^{185}$ Whether or not the victims objectively were members of these groups appears irrelevant, as long as the perpetrator treats them as such.

\section{Summary of Judicial Approaches to Race}

Apart from a purely objective approach to defining the protected groups of genocide, there are three possible subjective approaches: First, a perpetrator-based approach, where the perpetrator perceives the victim as belonging to a different group. ${ }^{186}$ Secondly, a victim-based approach, in which the victim perceives him- or herself as belonging to a group distinct from the perpetrator's. ${ }^{187}$ Lastly, an approach, which considers the perpetrator's as well as the victim's perception. ${ }^{188}$ The Darfur Commission apparently added yet another approach, namely the objectified subjective approach, whereby a subjective approach over time is hardened and acquires objectivity. The majority of judgments by the ad hoc tribunals favored a subjective approach based on the perception of the perpetrator, with due consideration of objective elements. ${ }^{189}$ These objective elements, however, remain undefined.

Recent jurisprudence suggests a trend of describing a racial group as a social construct, thus gradually abolishing contentious objective attributes. ${ }^{190}$ This development should be welcomed because it coheres with the genocidal dynamics. A perpetrator singles out for destruction a group that he considers to be different and inferior from his own. Whether the victim group is objectively different from the perpetrator is insignificant, as long as he perceives it to be. In addition, a subjective approach to race reflects the contemporary notion of the concept as a social construct or an imagined identity.

Nevertheless, a subjective approach that predominantly draws on the perception of the perpetrator, will not satisfactorily define the victim group. With an exclusive reliance on the perpetrator's perception, virtually any kind of group, imaginary or real, could become a target of genocide. International criminal law cannot permit the crime to be determined by the perpetrator alone, because the law was intended to exclusively protect the national, religious, ethnic and racial groups. ${ }^{191}$ The perception of differentness, upon which the subjective approach is built, has therefore to be restricted to the four groups in order to accord with the principle of legality.

The combination of an objective and a subjective perpetrator-based approach will not lead to a coherent result either. In Brđanin, the ICTY took precisely such a mixed approach, which is unsatisfactory because it does not disclose what objective elements are required for the legal definition of the protected group. ${ }^{192}$ The legal certainty and foreseeability are not strengthened by such an undefined approach. The weakness of this mixed approach can be demonstrated by a hypothetical example: If the definition of the protected groups is left to the fantasy of the perpetrator, then he could - theoretically - perceive women as a different group and single them out for destruction. These women are also an objective group, into which they were born and to which they have an irreversible chromosomal membership. If a racial group is defined as a group that is perceived as being different from another group, should women be classified as a different

\footnotetext{
${ }^{185}$ Ibid., para. 20.

${ }^{186}$ Lüders, Die Strafbarkeit von Völkermord, 55.

${ }^{187}$ Carola Lingaas, "The Elephant in the Room: The Uneasy Task of Defining Race in International Criminal Law," International Criminal Law Review 15 (2015), 509-511. 
race, because a male perpetrator could perceive them as such? This is obviously not the object and purpose of the genocide provisions.

Since apparently neither the objective nor the subjective approach nor a combination of both will result in a satisfactory definition a racial group, perhaps the theory of imagined identities will. The following conclusion will reveal that the theory of imagined identities can clear up the ambiguities and legal uncertainties.

\section{Conclusion}

International criminal jurisprudence increasingly acknowledges that collective identities are social constructs, so-called imagined identities that entirely depend on variable perceptions and not on facts. ${ }^{193}$ The four protected groups do not necessarily have to be objectively verifiable, but moreover depend on the perception of their differentness. This recognition should lead the legal community to accommodate for collective identities in general and race in particular. As suggested above, a purely subjective approach that builds on the perpetrator's perception and fantasy violates the principle of legality. According to that principle, criminal provisions have to be as specific and clear as possible in order to allow the perpetrator to foresee the consequences of his behavior and enable a court to pass judgments in a provable and consistent way. An expansion of the protected groups to include any subjectively perceived victim group would not pass the scrutiny of a court. However, the theory of imagined identities accommodates for the principles of foreseeability and specificity. Over the course of time, any initially subjective and imagined differences between the groups become solidified, effective and real, thereby providing the courts with the objectivity required in order to determine the victim groups of genocide.

By relying foremost on the perpetrator's perception of the victim group, the subjective approach also accommodates for contemporary views on race. Race is a social construct. There is no objective foundation for race, and an objective approach to determining the racial victim group in the crime of genocide is particularly problematic. As such, the perpetrator's perception of the victims' membership to a racial group becomes determinative for their protection from genocide. If the perpetrator perceives the victims as members of a distinct racial group, they are granted protection by the Genocide Convention.

The Darfur Commission's objectified subjective approach to defining the protected groups of genocide was innovative and ground-breaking. It relied on Benedict Anderson's theory of imagined communities, which was extrapolated into a theory of imagined identities, based on the victim's perceived or actual membership to one of the four protected group of genocide. In the theory of imagined identity, the victims' identification and group membership are determined by their effectiveness and operationability; as such they are treated as objective and real. For future criminal cases, in which the determination of a racial group is an issue, the respective court should not hesitate to apply the theory of imagined identities. It is a novel, contemporary and legally sound approach that allows courts to better tackle a difficult and sensitive topic: the issue of group membership and in particular race. The theory of imagined identity enables the identification of the racial group in that the group gains social and legal relevance once it is treated as real. In other words, if the perpetrator perceives his victims as members of a distinct racial group and treats them as such, namely by inferiorating and stigmatizing, the group acquires objectivity. Despite their imagined identity, the members of the racial victim group acquire an objectified existence by being treated as real.

Ultimately, the existence of a victim group is an issue of evidence: the prosecution would have to prove the perpetrator's perception rather than the objective existence of the group. Race is thereby removed from the objective elements of the crime, the acts reus. This solution is coherent with the principle of legality, whereby courts may not create a new criminal offence, but can adapt provisions to changing social conditions, such as broadening the actus reus. ${ }^{194}$ This is in essence the conclusion of the ICTR Muhimana trial judgment, according to which

\footnotetext{
${ }^{193}$ Verdirame, "The Genocide Definition", 592.

${ }^{194}$ Antonio Cassese, Cassese's International Criminal Law (Oxford: Oxford University Press, 2013), 32.
} 
[t]he Prosecution also has the burden of proving either that the victim belongs to the targeted ethnic, racial, national, or religious group or that the perpetrator of the crime believed that the victim belonged to the group. ${ }^{195}$

Muhimana thus gives the prosecution an alternative between proving the objective existence of a racial group, which would not be feasible, or the proof of the perpetrator's belief that the victim was member of such a group. In effect, it would result in releasing the racial group from the actus reus and fully including it into the mental elements, the mens rea.

The prosecution is thereby tasked to prove the perpetrator's intent to commit a genocidal act as well as the special intent to destroy a group. The protected group of genocide itself is also added to the prosecutorial burden. This might seem an unachievable task. However, the perpetrator's perception of the victim group will inevitably manifest itself in his behavior. As has been demonstrated above, the othering of the victim group becomes observable in any pre-genocidal process. The perpetrator's behavior becomes the key to determining the othering and his understanding of the victim group. The behavior becomes apparent in posters, books, pamphlets, but also radio broadcasts, personal statements, correspondence and the like. If this behavior is characterized by othering, namely the dehumanization of the victims, there is a clear and unequivocal indication of his perception of the group and the ensuing genocidal intent. The perpetrator's behavior is observable and will provide the foundation for a legal classification of the victim group. The solution lies in the mind of the perpetrator and in the way that he perceives the victim group. The legal definition of the national, racial, ethnical and religious group in the crime of genocide has to be seen through the eyes of the perpetrator.

\section{Bibliography}

Akhavan, Payam. Reducing Genocide to Law: Definition, Meaning, and the Ultimate Crime. Cambridge: Cambridge University Press, 2012. http://dx.doi.org/10.1017/CBO9781139028943

Akhavan, Payam. "The Crime of Genocide in the ICTR Jurisprudence." Journal of International Criminal Justice 3 (2005): 989-1006. http://dx.doi.org/10.1093/jicj/mqi060

Allard K. Lowenstein International Human Rights Clinic, Yale Law School. Persecution of the Rohingya Muslims: Is Genocide Occurring in Myanmar's Rakhine State? A Legal Analysis. 2015.

Amann, Diane. "Group Mentality, Expressivism, and Genocide." International Criminal Law Review 2 (2002): 93-143. http://dx.doi.org/10.1163/157181202400454709

Amann, Diane. "Prosecutor v. Akayesu." American Journal of International Law 93 (1999): 195-199. http://dx.doi.org/10.2307/2997961

American Anthropological Association. Statement on 'Race', 1998. Accessed April 7, 2016. http://www.aaanet.org/stmts/racepp.htm.

Anderson, Benedict. Imagined Communities: Reflections on the Origin and Spread of Nationalism. London: Verso, 2006.

Banton, Michael. International Action against Racial Discrimination. Oxford: Clarendon Press, 1996. http://dx.doi.org/10.1093/0198280610.001.0001

Banton, Michael. Racial Theories. Cambridge: Cambridge University Press, 1998. http://dx.doi. org/10.1017/CBO9780511583407

Banton, Michael. What We Know about Race and Ethnicity. New York: Berghahn Books, 2015.

Bassiouni, Cherif M. The Legislative History of the International Criminal Court, Summary Records of the 1998 Diplomatic Conference, Vol. 3. New York: Transnational Publishers, 2005.

Berreby, David. Us and Them: The Science of Identity. Chicago: The University of Chicago Press, 2008.

Berster, Lars. "Article II." In Convention on the Prevention and Punishment of the Crime of Genocide: A Commentary, edited by Christian Tams, Lars Berster and Björn Schiffbauer, 79-156. Munich: C.H. Beck, 2014. http://dx.doi.org/10.5771/9783845258911 126

Bobo, Lawrence. "Foreword." In Revisiting Race in a Genomic Age, edited by Barbara Koenig, Sandra Soo-Jin Lee and Sarah S. Richardson, ix-xii. New Brunswick: Rutgers University Press, 2008.

${ }^{195}$ The Prosecutor v. Muhimana, Trial Chamber Judgment, April 28, 2005, ICTR-95-1B-T, para. 500. 
Boot, Machteld. Genocide, Crimes Against Humanity, War Crimes: Nullum Crimen Sine Lege and the Subject Matter Jurisdiction of the International Criminal Court. Antwerpen, Intersentia, 2002.

Brubaker, Rogers. "The Dolezal Affair: Race, Gender, and the Micropolitics of Identity." Ethnic and Racial Studies 39 (2016): 414-448. http://dx.doi.org/10.1080/01419870.2015.1084430

Brubaker, Rogers. "Ethnicity, Race, and Nationalism." Annual Review of Sociology 35 (2009): 21-42. http://dx.doi.org/10.1146/annurev-soc-070308-115916

Cassese, Antonio. Cassese's International Criminal Law. Oxford: Oxford University Press, 2013. http://dx.doi.org/10.1093/he/9780199694921.001.0001

Cassese, Antonio. International Criminal Law. Oxford: Oxford University Press, 2008.

Chalk, Frank and Jonassohn, Kurt. The History and Sociology of Genocide: Analyses and Case Studies. New Haven: Yale University Press, 1990.

Cooper, Richard, Kaufman, Jay and Ward, Ryk. "Race and Genomics." New England Journal of Medicine 348 (2003): 1166-1170. http://dx.doi.org/10.1056/NEJMsb022863

Cosmides, Leda, Tooby, John and Kurzban, Robert. "Perceptions of Race." Trends in Cognitive Sciences (2003): 173-179. http://dx.doi.org/10.1016/S1364-6613(03)00057-3

Davis, David. "Constructing Race: A Reflection." The William and Mary Quarterly: A Magazine of Early American History and Culture 54 (1997): 7-18.

Deutsch, David and Yanay, Niza. "The Politics of Intimacy: Nazi and Hutu Propaganda as Case Studies." Journal of Genocide Research 18 (2016): 21-39. http://dx.doi.org/10.1080/14623528.2 016.1120461

De Waal, Alex. "Genocide in Rwanda." Anthropology Today 10 (1994): 1-2. http://dx.doi. org $/ 10.2307 / 2783474$

De Waal, Alex. “Group Identity, Rationality, and the State." Critical Review 11 (1997): 279-289. http://dx.doi.org/10.1080/08913819708443457

Drumbl, Mark. Atrocity, Punishment, and International Law. Cambridge: Cambridge University Press, 2007. http://dx.doi.org/10.1017/CBO9780511611100

Eriksen, Thomas Hylland. Ethnicity and Nationalism. London: Pluto Press, 2010.

Extraordinary Chambers in the Courts of Cambodia. "Case 002/02." Accessed May 18, 2016. http://www.eccc.gov.kh/en/case/topic/1299.

Fournet, Caroline. "The Actus Reus of Genocide." In Elements of Genocide, edited by Paul Behrens and Ralph Henham, 53-69. Abingdon: Routledge, 2013.

Fournet, Caroline. The Crime of Destruction and the Law of Genocide: Their Impact on Collective Memory. Aldershot: Ashgate, 2007.

Gallant, Kenneth. The Principle of Legality in International and Comparative Criminal Law. Cambridge: Cambridge University Press, 2009.

Gilroy, Paul. Against Race: Imagining Political Culture Beyond the Color Line. Cambridge: Harvard University Press, 2000.

Glaser, Kurt and Possony, Stefan. Victims of Politics: The State of Human Rights. New York, Columbia University Press, 1979.

Grady, Katy. “The Genocide Convention's Protected Groups: A Place for Gender?" In Protecting Humanity: Essays in International Law and Policy in Honour of Navanethem Pillay, edited by Chile Eboe-Osuji, 165-184. Leiden: Martinus Nijhoff Publishers, 2010. http://dx.doi. org/10.1163/ej.9789004183780.i-882.42

Hagan, John and Rymond-Richmond, Wenona. Darfur and the Crime of Genocide. Cambridge: Cambridge University Press, 2009.

Hague, Euan. "Benedict Anderson." In Key Thinkers on Space and Place, edited by Phil Hubbard and Rob Kitchin, 16-21. London: Sage Publications, 2011.

Hardin, Russell. One for All: The Logic of Group Conflict. Princeton: Princeton University Press, 1995.

Hayden, Robert. "Imagined Communities and Real Victims: Self-Determination and Ethnic Cleansing in Yugoslavia." In Genocide: An Anthropological Reader, edited by Alexander Laban Hinton, 231-253. Malden: Blackwell Publishers, 2002.

Hinton, Alexander Laban. "The Dark Side of Modernity." In Annihilating Difference: the Anthropology of Genocide, edited by Alexander Laban Hinton, 1-40. Berkeley: University of California Press, 2002. 
Hoffman, Sharona. "Is There a Place for "Race" as a Legal Concept?" Arizona State Law Journal 36 (2004): 1093-1159.

Holslag, Anthonie. “The Process of Othering from the 'Social Imaginaire' to Physical Acts: An Anthropological Approach." Genocide Studies and Prevention: An International Journal 9 (2015): 96-113. http://dx.doi.org/10.5038/1911-9933.9.1.1290

Howard, Erica. "Race and Racism: Why does European Law have Difficulties with Definitions?" The International Journal of Comparative Labour Law and Industrial Relations 24 (2008): 5-29.

International Law Commission. Report of the ILC on the work of its forty-eighth session. May 6 -July 26, 1996. UN Doc. A/51/10.

Kielsgard, Mark. Responding to Modern Genocide: At the Confluence of Law and Politics. Abingdon: Routledge, 2016.

Kiernan, Ben. Blood and Soil: A World History of Genocide and Extermination from Sparta to Darfur. New Haven: Yale University Press, 2007.

King, Henry Jr. "Genocide and Nuremberg." In The Criminal Law of Genocide, edited by Ralph Henham and Paul Behrens, 29-35. Aldershot: Ashgate, 2007.

Klamberg, Mark. Evidence in International Criminal Trials: Confronting Legal Gaps and the Reconstruction of Disputed Events. Leiden: Martinus Nijhoff Publishers, 2013. http://dx.doi. org/10.1163/9789004236523

Klann, Helen and McKenzie, Phillipa. "Judge Laïty Kama: Five Cases to Develop International Criminal Law." In From Human Rights to International Criminal Law: Studies in Honour of an African Jurist, the Late Judge Laïty Kama, edited by Emmanuel Decaux, Adama Dieng and Malick Sow, 15-54. Leiden: Martinus Nijhoff Pubishers, 2007. http://dx.doi.org/10.1163/ ej. $9789004160552 . i-776.7$

Kress, Claus. "The Crime of Genocide Under International Law." International Criminal Law Review 6 (2006): 461-502. http://dx.doi.org/10.1163/157181206778992287

LeBlanc, Lawrence. "The United Nations Genocide Convention and political groups: should the United States propose an amendment?" Yale Journal of International Law 13 (1998): 268-295.

Lemkin, Raphael. Axis Rule in Occupied Europe: Laws of Occupation, Analysis of Government, Proposals for Redress. Washington: Carnegie Endowment for International Peace, Division of International Law, 1944.

Lingaas, Carola. "The Elephant in the Room: The Uneasy Task of Defining Race in International Criminal Law." International Criminal Law Review 15 (2015): 485-516. http://dx.doi. org/10.1163/15718123-01503002

Lippman, Matthew. “Genocide.” In International Criminal Law: Sources, Subjects, and Contents, edited by M. Cherif Bassiouni, 403-435. Leiden: Martinus Nijhoff Publishers, 2008.

Lippman, Matthew. "Genocide: The Crime of the Century. The Jurisprudence of Death at the Dawn of the New Millenium." Houston Journal of International Law 23 (2000): 467-535.

Lisson, David. "Defining 'National Group' in the Genocide Convention: a Case Study of TimorLeste." Stanford Law Review (2008): 1459-1496.

López, Ian Haney. White by Law: The Legal Construction of Race. New York: New York University Press, 2006.

Lüder, Barbara. Die Strafbarkeit von Völkermord nach dem Römischen Statut für den Internationalen Strafgerichtshof. Berlin: Berliner Wissenschafts-Verlag, 2004.

Martin, Fanny. "The Notion of 'Protected Group' in the Genocide Convention and its Application." In The UN Genocide Convention: A Commentary, edited by Paola Gaeta, 112-127. Oxford: Oxford University Press, 2009.

Meron, Theodor. War Crimes Law Comes of Age: Essays. Oxford: Clarendon Press, 1998.

Moshman, David. "Us and Them: Identity and Genocide." Identity: An International Journal of Theory and Research 7, No. 2 (2007): 115-135. http://dx.doi.org/10.1080/15283480701326034

Nagan, Winston and Rodin, Vivile. "Racism, Genocide, and Mass Murder: Towards a Legal Theory about Group Deprivations." National Black Law Journal 17 (2002-2004): 133-221.

Nersessian, David. Genocide and Political Groups. Oxford: Oxford University Press, 2010. http://dx.doi.org/10.1093/acprof:oso/9780199588909.001.0001 
Nersessian, David. “The Razor's Edge: Defining and Protecting Human Groups under the Genocide Convention." Cornell International Law Journal 36 (2003): 293-327.

Ntanda Nsereko, Daniel. "Genocide: a crime against mankind." In Substantive and Procedural Aspects of International Criminal Law, edited by Gabrielle Kirk McDonald and Olivia SwaakGoldman, 113-140. The Hague: Kluwer Law, 2000.

Pronk, Jan. "The United Nations After 50 Years." In Contemporary Genocides: Causes, Cases, Consequences, edited by Albert Jongman, iii-xvi. Leiden: PIOOM, 1996.

Ratner, Steven and Abrams, Jason. Accountability for Human Rights Atrocities in International Law: Beyond the Nuremberg Legacy. New York: Oxford University Press, 1997.

Quayle, Peter. "Unimaginable Evil: The Legislative Limitations of the Genocide Convention." International Criminal Law Review 5 (2005): 363-372. http://dx.doi. org/10.1163/1571812054940120

Quigley, John. The Genocide Convention: An International Law Analysis. Aldershot: Ashgate, 2006.

Schabas, William. Genocide in International Law. Cambridge: Cambridge University Press, 2009. http://dx.doi.org/10.1017/CBO9780511575556

Schabas, William. "Groups Protected by the Genocide Convention." ILSA Journal for International and Comparative Law 6 (2000): 375-387.

Schabas, William. "Judicial Activism and the Crime of Genocide." In Judicial Creativity at the International Criminal Tribunals, edited by Shane Darcy and Joseph Powderly, 63-79. Oxford: OxfordUniversity Press, 2010.http://dx.doi.org/10.1093/acprof:oso/9780199591466.003.0004

Schabas, William. "The Crime of Genocide in the Jurisprudence of the International Criminal Tribunals for the Former Yugoslavia and Rwanda." In International and National Prosecution of Crimes Under International Law, edited by Horst Fischer, Claus Kress and Sascha Rolf Lüder, 447-471. Berlin: Berlin Verlag, 2001.

Schabas, William. The UN International Criminal Tribunals: the Former Yugoslavia, Rwanda and Sierra Leone. Cambridge: Cambridge University Press, 2006. http://dx.doi.org/10.1017/ CBO9780511617478

Schuster, Matthias. "The Crime of Genocide Applied in Practice: Selected Aspects of the Jurisprudence of the Ad Hoc Tribunals' Appeals Chambers." In The Genocide Convention Sixty Years After its Adoption, edited by Christoph Safferling and Eckart Conze, 213-234. The Hague: TMC Asser Press, 2010.

Sluiter, Göran. "Ad hoc International Criminal Tribunals (Yugoslavia, Rwanda, Sierra Leone)." In The Cambridge Companion to International Criminal Law, edited by William Schabas. 117-136. Cambridge: Cambridge University Press, 2016. http://dx.doi.org/10.1017/ CBO9781107280540.007

Stanton, Gregory. Countries at Risk Report 2012. Washington: Genocide Watch, 2012.

Stanton, Gregory. "Could the Rwandan Genocide Have Been Prevented?" Journal of Genocide Research 6 (2004): 211-228. http://dx.doi.org/10.1080/1462352042000225958

Straus, Scott. "Contested Meanings and Conflicting Imperatives: a Conceptual Analysis of Genocide." Journal of Genocide Research 3 (2001): 349-375. http://dx.doi.org/10.1080/14623520120097189

Straus, Scott. The Order of Genocide: Race, Power, and War in Rwanda. Ithaca: Cornell University Press, 2006.

Sunga, Lyal. The Emerging System of International Criminal Law: Developments in Codification and Implementation. The Hague, Kluwer Law International, 2010.

Szpak, Agnieszka. "National, Ethnic, Racial, and Religious Groups Protected against Genocide in the Jurisprudence of the Ad Hoc International Criminal Tribunals." European Journal of International Law 23 (2012): 155-173. http://dx.doi.org/10.1093/ejil/chs002

United Nations. Preliminary Report of the Independent Commission of Experts Established in Accordance with Security Council Resolution 935, October 4, 1994. UN Doc. S/1994/1125 (1994).

United Nations. Report of the Group of Experts for Cambodia Established Pursuant to General Assembly Resolution 52/135, March 15, 1999. UN Doc. A/53/850 and S/1999/231.

United Nations. Report of the International Commission of Inquiry on Darfur, January 25, 2005. UN Doc. $\mathrm{S} / 2005 / 60$. 
United Nations Educational, Scientific and Cultural Organization. "Statement on Race 1950." In Four Statements on the Race Question, edited by UNESCO, 1969.

United Nations Educational, Scientific and Cultural Organization. "Statement on Race and Racial Prejudice of 1967." In Four Statements on the Race Question, edited by UNESCO, 1969.

Van den Herik, Larissa. The Contribution of the Rwanda Tribunal to the Development of International Law. Leiden: Martinus Nijhoff, 2005.

Van Schaack, Beth. "Darfur and the Rhetoric of Genocide." Whittier Law Review 26 (2005): 1101-1141.

Van Schaack, Beth. "Crimen Sine Lege: Judicial Lawmaking at the Intersection of Law and Morals." Georgetown Law Journal 97 (2008): 119-192.

Verdirame, Guglielmo. "The Genocide Definition in the Jurisprudence of the ad hoc Tribunals." International and Comparative Law Quarterly 49 (2000): 578-598. http://dx.doi.org/10.1017/ $\underline{\mathrm{S} 002058930006437 \mathrm{X}}$

Vest, Hans. Genozid durch organisatorische Machtapparate, Baden-Baden: Nomos, 2002.

Villiger, Mark. Commentary on the 1969 Vienna Convention on the Law of Treaties. Leiden: Martinus Nijhoff Publishers, 2009.

Von Hebel, Hermann and Robinson, Darryl. "Crimes Within the Jurisdiction of the Court." In The International Criminal Court: The Making of the Rome Statute - Issues, Negotiations, Results, edited by Roy Lee, 79-126. The Hague: Kluwer Law International, 1999.

Werle, Gerhard. Principles of International Criminal Law. The Hague: T.M.C. Asser Press, 2005.

Werle, Gerhard and Jessberger, Florian. Principles of International Criminal Law. Oxford: Oxford University Press, 2014.

Whitaker, Benjamin. Revised and Updated Report on the Question of the Prevention and Punishment of the Crime of Genocide. UN Doc. E/CN.4/Sub.2/1985/6, July 2, 1985.

Wilson, Richard Ashby. "Crimes against Humanity and the Conundrum of Race and Ethnicity at the International Criminal Tribunal for Rwanda." In In the Name of Humanity: The Government of Threat and Care, edited by Ilana Feldman and Miriam Ticktin, 27-57. Durham: Duke University Press, 2010. http://dx.doi.org/10.1215/9780822393221-002

Yudell, Michael. Race Unmasked: Biology and Race in the Twentieth Century. New York: Columbia University Press. 2014. http://dx.doi.org/10.7312/columbia/9780231168748.001.0001 